\section{Pacific Northwest}

National Laboratory

Operated by Battelle for the

U.S. Department of Energy

\title{
Analysis of Potential Benefits and Costs of Adopting ASHRAE Standard 90.1-1999 as a Commercial Building Energy Code in Michigan
}

KA Cort

DB Belzer

M Halverson

EE Richman

DW Winiarski

September 2002

Prepared for the U.S. Department of Energy under Contract DE-AC06-76RL01830 


\title{
DISCLAIMER
}

This report was prepared as an account of work sponsored by an agency of the United States Government. Neither the United States Government nor any agency thereof, nor Battelle Memorial Institute, nor any of their employees, makes any warranty, express or implied, or assumes any legal liability or responsibility for the accuracy, completeness, or usefulness of any information, apparatus, product, or process disclosed, or represents that its use would not infringe privately owned rights. Reference herein to any specific commercial product, process, or service by trade name, trademark, manufacturer, or otherwise does not necessarily constitute or imply its endorsement, recommendation, or favoring by the United States Government or any agency thereof, or Battelle Memorial Institute. The views and opinions of authors expressed herein do not necessarily state or reflect those of the United States Government or any agency thereof.

\author{
PACIFIC NORTHWEST NATIONAL LABORATORY \\ operated by \\ BATTELLE \\ for the \\ UNITED STATES DEPARTMENT OF ENERGY \\ under Contract DE-AC06-76RL01830
}

Printed in the United States of America

Available to DOE and DOE contractors from the

Office of Scientific and Technical Information,

P.O. Box 62, Oak Ridge, TN 37831-0062;

ph: (865) 576-8401

fax: (865) 576-5728

email: reports@adonis.osti.gov

\footnotetext{
Available to the public from the National Technical Information Service, U.S. Department of Commerce, 5285 Port Royal Rd., Springfield, VA 22161 ph: (800) 553-6847 fax: (703) 605-6900 email: orders@ntis.fedworld.gov online ordering: http://www.ntis.gov/ordering.htm
}

This document was printed on recycled paper.

$(8 / 00)$ 


\section{Analysis of Potential Benefits and Costs of Adopting ASHRAE Standard 90.1-1999 as a Commercial Building Energy Code in Michigan}

September 2002

Completed for the Building Standards and Guidelines Program, U.S. Department of Energy

Completed by Pacific Northwest National Laboratory, Operated for the U.S. Department of Energy by Battelle 


\section{Executive Summary}

ANSI/ASHRAE/IESNA Standard 90.1-1999 Energy Standard for Buildings except LowRise Residential Buildings (hereafter referred to as ASHRAE 90.1-1999 or 90.1-1999) was developed in an effort to set minimum requirements for the energy efficient design and construction of new commercial buildings. The State of Michigan is considering adopting ASHRAE 90.1-1999 as its commercial building energy code. In an effort to evaluate whether or not this is an appropriate code for the state, the potential benefits and costs of adopting this standard are considered in this report. Both qualitative and quantitative benefits and costs are assessed. Energy and economic impacts are estimated using the Building Loads Analysis and System Thermodynamics (BLAST) simulations combined with a Life-Cycle Cost (LCC) approach to assess corresponding economic costs and benefits. Michigan currently has ASHRAE Standard 90A-1980 as the statewide commercial energy code; thus, many of the requirements of ASHRAE 90A1980 were used as a baseline for simulations.

The energy simulation and economic results of the building prototypes chosen for this study suggest that adopting ASHRAE 90.1-1999 as the commercial building energy code in Michigan would provide positive net benefits to the state relative to the building and design requirements prescribed in ASHRAE 90A-1980. For most requirements, the adoption of ASHRAE 90.1-1999 increases first costs, but decreases annual energy costs. The overall impact is that the ASHRAE 90.1-1999 standard has positive net benefits relative to the requirements of ASHRAE 90A-1980.

A discussion is also provided to explain additional decreases in energy that result from ASHRAE 90.1-1999 requirements that were not included in the quantitative modeling analysis. In addition, if ASHRAE 90.1-1999 were adopted as code in its entirety, which includes the addition of commercial building renovation, it could further increase the energy efficiency of commercial buildings.

Finally, ASHRAE 90.1-1999 provides some qualitative improvements over the ASHRAE 90.1-1989 standard that makes adoption more desirable. For example, ASHRAE 90.11999 is written in more mandatory, enforceable language, which makes it easier to enforce. It also improves the format of many of the reference tables so that it is easier to follow and, therefore, easier with which to comply. 


\section{Contents}

1.0 INTRODUCTION.............................................................................................. 1

1.1 OBJECTIVE

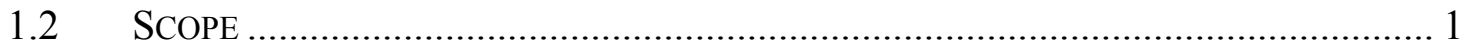

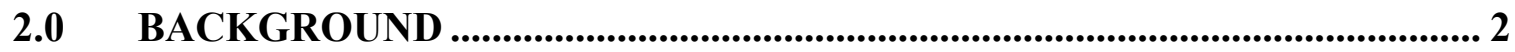

2.1 SuMMARY OF DifFERENCES BETWEEN STANDARDS …………………….......... 2

2.1.1 Building Envelope Standard Changes ................................................. 2

2.1.2 Lighting Standard Changes ............................................................... 3

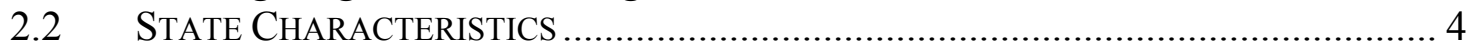

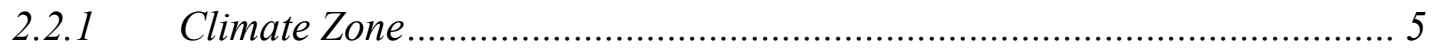

2.2.2 Demographic and Construction Data................................................... 5

2.2.3 Energy Consumption and Sources ..................................................... 5

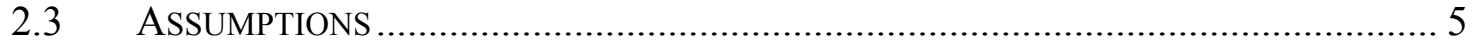

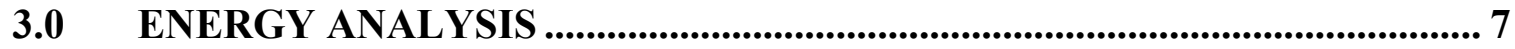

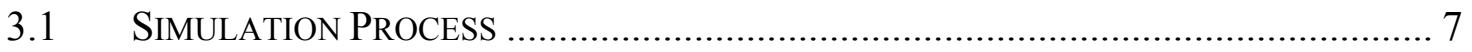

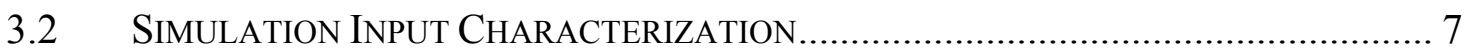

3.2.1 Building Envelope Inputs............................................................... 7

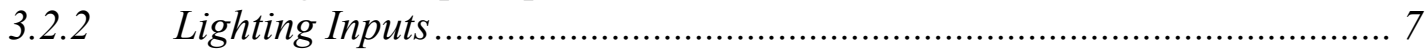

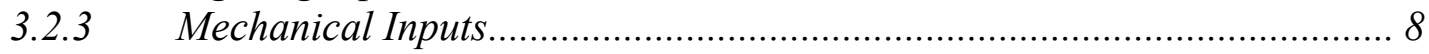

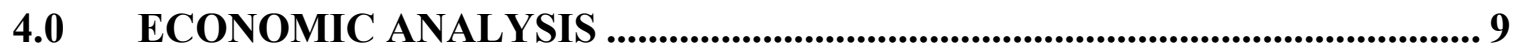

4.1 BUILDING ENVELOPE ANALYSIS ......................................................................... 10

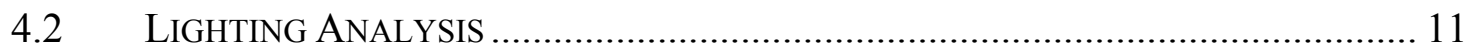

5.0 QUANTITATIVE RESULTS .......................................................................... 15

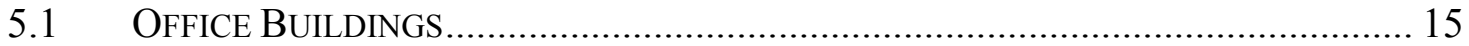

5.1.1 Impact of Changing Window-to-Wall Ratios......................................... 19

5.1.2 Impact of Changing Building Size ...................................................... 21

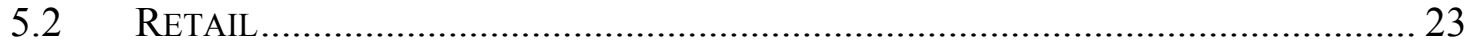

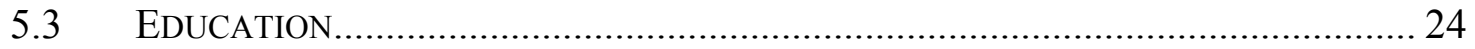

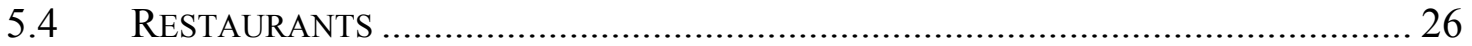

5.5 OTHER FACTORS IMPACTING BENEFITS AND COSTS ......................................... 26

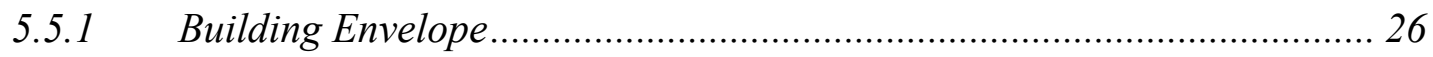

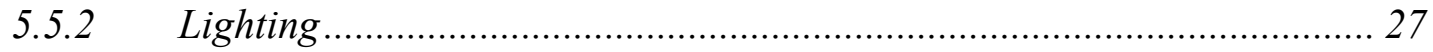

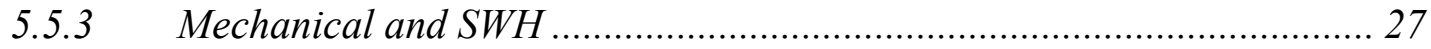

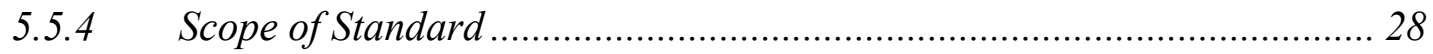

6.0 QUALITATIVE CONSIDERATIONS.............................................................. 29

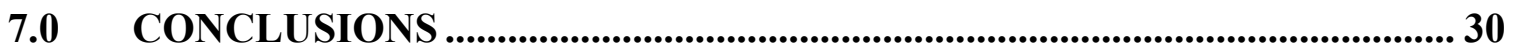

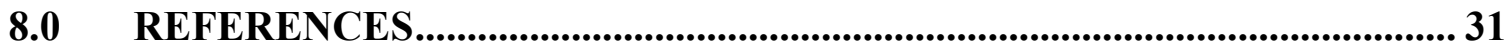

Appendix A Glossary of Selected Terms ................................................................... 33

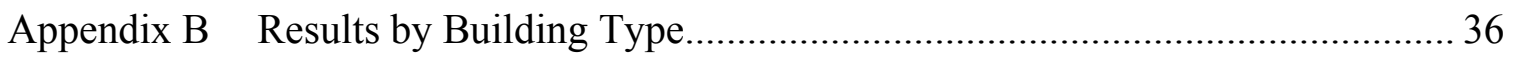




\section{Acronyms and Abbreviations}

\begin{tabular}{|c|c|}
\hline $\mathrm{ACP}$ & Alternate Component Packages \\
\hline AIRR & Adjusted internal rate of return \\
\hline ASHRAE & American Society of Heating, Refrigerating and Air-Conditioning Engineers \\
\hline BLAST & Building Loads Analysis and System Thermodynamics \\
\hline BLCC & Building Life-Cycle Cost \\
\hline CBECS & Commercial Buildings Energy Consumption Survey \\
\hline CDD & Cooling Degree-Days \\
\hline CFL & Compact Fluorescent Light \\
\hline DOE & U.S. Department of Energy \\
\hline EIA & Energy Information Administration \\
\hline EPCA & Energy Policy and Conservation Act \\
\hline EUIs & Energy Use Intensities \\
\hline FEMP & Federal Energy Management Program \\
\hline HDD & Heating Degree-Days \\
\hline HID & High Intensity Discharge \\
\hline HVAC & Heating, Ventilation, and Air-Conditioning \\
\hline IES & Illuminating Engineering Society \\
\hline $\mathrm{LCC}$ & Life-Cycle Cost \\
\hline LPD & Lighting Power Densities \\
\hline NEMS & National Energy Modeling System \\
\hline NIST & National Institute of Standards and Technology \\
\hline OMB & Office of Management and Budget \\
\hline PNNL & Pacific Northwest National Laboratory \\
\hline $\mathrm{SC}$ & Shading Coefficient \\
\hline SIR & Savings-to-Investment Ratio \\
\hline SWH & Service Water Heating \\
\hline TMY & Typical Metrological Year \\
\hline TSD & Technical Support Document \\
\hline
\end{tabular}

(Glossary of selected terms found in Appendix A) 



\subsection{Introduction}

\subsection{Objective}

The state of Michigan has ASHRAE Standard 90A-1980 as the statewide building energy efficiency code. This report was prepared in response to a request for technical assistance from the State of Michigan's Energy Office. The request specified the need for an objective analysis that would assess the impacts of adopting ASHRAE 90.1-1999 as the state commercial building energy code. The request specified that the analysis focus on at least one predominant prototypical commercial building (e.g., office) located in one of Michigan's major cities.

\subsection{Scope}

This report provides an analysis with the scope limited to office, retail, education, and restaurant buildings, as these building types made up over $50 \%$ of the total value of new commercial construction in Michigan in 1997 (Census 2000c). Within these building types, the impacts of the building envelope and lighting requirements are assessed, while mechanical requirements are excluded because of expected changes in efficiencies due to federal manufacturing standards as referenced under the Energy Policy and Conservation Act (EPCA) as amended by the 1992 Energy Policy Act (EPAct).

Under this legislation, the energy efficiency of most of the heating cooling, air conditioning (HVAC) and service water heating $(\mathrm{SWH})$ equipment regulated under ASHRAE 90.1-1999 is also regulated by federal manufacturing standards, which by law will soon be updated to levels at least as stringent as those in 90.1-1999. Hence, the savings from these equipment requirements will generally occur regardless of the adoption of a building standard in Michigan. Efficiency improvements in equipment that are not covered under EPCA are discussed in Section 5.4 of this report along with other requirements in the HVAC and SWH section of the standard. The potential quantitative impact of the equipment standards has been evaluated in detail in the report, Screening Analysis for EPACT-Covered Commercial HVAC and Water heating Equipment.

The study period is forty years. This time horizon was chosen to capture changes in building energy consumption from required energy-related designs and materials that occur over the life of the building. Specific simulation and Life Cycle Cost (LCC) assumptions are discussed in the respective sections of this report.

This report includes a summary of background information regarding various building code requirements, state-specific information, and a description of the assumptions required to complete the quantitative analysis. The report includes sections that describe the building simulation process as well as the economic model and the assumptions used to calculate LCC savings for each building type. Detailed quantitative results are included in the appendix and discussed in Section 5. Finally, a discussion addressing benefits and costs associated with the adoption of the latest ASHRAE standard that are not specifically addressed in the quantitative study is included in the final sections of this report 


\subsection{Background}

Energy codes set minimum standards for design and construction while ensuring occupant comfort. These codes eliminate building design practices that lead to unnecessarily high building energy use and associated costs. Energy cost savings resulting from energy code compliance directly benefit building owners and occupants over the life cycle of the building. An energy code, however, may impose higher initial costs on the building owner, as frequently the incentive is to use equipment and materials that have lower first costs and lower efficiencies. The energy savings also reduce the need for new generating and transmission capacity, and detrimental environmental effects associated with energy production, distribution, and use.

In 1977, the state of Michigan adopted ASHRAE /IES Standard 90-1975 as the commercial building energy code statewide. In 1985 ANSI/ASHRAE/IES Standard 90A-1980 was adopted as the statewide commercial building energy code. The state energy code is evaluated for revisions or modifications every three years. The new code requirements are adopted at the beginning of each state building code cycle.

Since the writing of ASHRAE 90A-1980, ASHRAE and other organizations involved in code development have created various updated versions of the commercial building energy codes, including the 90.1-1989 version and most recently, 90.1-1999. Each version of the standard is based on materials and technologies that are available during the writing of the standard. Since ASHRAE 90A-1980 was written, technological advances have improved the efficiency of much of the lighting and mechanical equipment available to builders. Because the baseline technology has progressed beyond the 90A-1980 levels for lighting and mechanical equipment in many cases, this study will use 90.1-1989 requirements to reflect baseline lighting and mechanical design and equipment rather than 90A-1980 requirements. The 90A-1980 requirements, however, will be used to describe all baseline envelope characteristics.

\subsection{Summary of Differences between Standards}

\subsubsection{Building Envelope Standard Changes}

Building envelope requirements apply to conditioned (i.e. heated and cooled) spaces that are separated from unconditioned spaces. The requirements cover materials such as windows, doors, and insulation for roofs, walls, and floors and vary by climate. The portion of ASHRAE Standard 90A and 90.1 with the building envelope requirements includes mandatory requirements in both the 1980 and 1999 editions. Standard 90A1980 contains a set of charts, graphs, and equations that must be solved to obtain envelope requirements, while Standard 90.1-1999 contains sets of prescriptive requirements for envelopes along with a performance-based tradeoff approach. Standard 90A-1980 specifies U-factors for total assemblies (roofs including skylights, walls including windows) based on properties of the assembly while the1999 version specifies 
U-factors for specific types of roofs, walls, windows, and skylights. The 90.1-1999 standard has added air leakage requirements, which apply to the Michigan climates, for the sealing of openings and joints in the building envelope (including windows and doors, loading docks, and vestibules). The prescriptive path of the 1999 edition adds an appendix of pre-calculated assemblies (U-factors, C-factors, and F-factors).

The general difference between ASHRAE 90A-1980 and 90.1-1999 is the approach used to justify the minimum requirements. The envelope requirements of ASHRAE 90A-1980 were developed based on professional judgment. ASHRAE 90.1-1999 is based on economic justification of energy efficiency measures. The envelope requirements in ASHRAE 90.1-1999 were developed using a life cycle cost process that balanced the energy savings achieved against the first cost of extra materials and equipment to obtain that level of efficiency. So there is an obvious difference between ASHRAE 90A-1980's "energy savings" and ASHRAE 90.1-1999's "cost justified energy savings".

One other difference between the ASHRAE 90A-1980 standard and the 90.1-1999 standard is that 1980 version is based on a series of continuous curves of efficiency, leading to continuously changing requirements by climate. The 1999 version is based on a "step-function" approach. Thus, the1980 standard may have wall requirements for the equivalent for R-5.4, R-7.2, R-8.6, R-9, R-10, R-11.3 for various locations (where no actual product on the market precisely meets these specific requirements) where the 1999 standard may have either R-7 or R-11 or R-13. The resulting impact of the 90A1980 requirements is that in order to meet the requirements, one would typically need to exceed the prescriptive requirements in order find a commercially available product at the required level. To find the 90.1-1999 requirements, only commercially available R-value insulation was considered and the fuel cost savings achieved from going to the next level had to pay for the incremental first cost.

\subsubsection{Lighting Standard Changes}

The ASHRAE 90.1-1989 section on lighting includes both mandatory provisions and a prescriptive path to determine compliance. The 1989 mandatory requirements cover minimum lighting controls and their accessibility and include restrictions on single-lamp ballasts when more efficient multiple-lamp ballasts can be used. The 90.1-1989 standard includes efficiency requirements for ballasts, which have been absorbed into federal manufacturing standards under EPCA. Automatic controls are not required in the 1989 standard but credits allowing higher lighting power densities (LPDs) were allowed if occupancy, lumen maintenance, and/or daylight sensors are installed.

Whole building lighting power densities are considered the most reasonable and practical method of comparing lighting requirements. However, the 90.1-1989 standard provides direct lighting densities for only a few building categories and sizes. Therefore, LPDs for whole buildings used in this comparison were calculated on a space-by-space basis that is similarly represented in both the 1989 and 1999 editions of the standard. This provides the most directly comparable basis between the two standards. Space-by-space numbers in the 1989 standard are used as a base value and an adjustment factor is applied for each space to adjust for room size and ceiling height to make them comparable in application to the corresponding 1999 space-by-space power densities. 
The mandatory provisions in ASHRAE 90.1-1999 focus on lighting controls and efficient use of lighting ballasts. The primary requirement is an automatic lighting control, which consists of a programmable whole building lighting shutoff control, occupancy sensor, or similar automatic lighting shutoff control system. Other control requirements define limits for area control of lighting, use of photosensor or timeclock controls for exterior lights, and additional control of specific lighting tasks. The use of less efficient singlelamp fluorescent ballasts is reduced through tandem wiring requirements. The mandatory section also defines calculation of fixture wattage and sets power limits for exit signs and exterior lighting.

The ASHRAE 90.1-1999 prescriptive path includes interior and exterior lighting power allowances, where the interior lighting power allowances may be determined by using either the total building area or the space-by-space (e.g., office, hallway) method. Interior lighting power requirements allow for design differences and special lighting needs by providing power allowances for decorative, display, accent lighting, merchandise highlighting, and computer screen glare reduction in specified spaces. Lighting excluded from the code is identified for specific tasks or applications such as safety lighting and lighting within living units. Exterior lighting, used at building entrances and exits and for building highlighting, has specified power limits while all other exterior grounds lighting is limited only by the efficiency of the light source itself.

Table 1 shows a comparison of the requirements in 1989 and 1999 editions for some selected lighting power density allowances using the whole building and space-by-space methods.

Table 1. Comparison of Lighting Power Densities - Standards 90.1-1989 and 90.1-1999

\begin{tabular}{|l|c|c|c|c|c|}
\hline \multicolumn{2}{|c|}{$\begin{array}{c}\text { Whole Building Method } \\
\left.\text { Lighting Power Densities (W/ft }{ }^{2}\right)\end{array}$} & \multicolumn{3}{c|}{$\begin{array}{c}\text { Space-by-Space Method } \\
\text { Lighting Power Densities }\end{array}$} \\
\hline Building Type & $\begin{array}{c}\mathbf{1 9 9 9} \\
\text { Edition }\end{array}$ & $\begin{array}{c}\mathbf{1 9 8 9} \\
\text { Edition }\end{array}$ & \multicolumn{1}{|c|}{ Space Type } & $\begin{array}{c}1999 \\
\text { Edition }\end{array}$ & $\begin{array}{c}1989 \\
\text { Edition }\end{array}$ \\
\hline Hospital & 1.6 & NA & Office Enclosed & 1.5 & 1.8 \\
\hline Library & 1.5 & NA & Office Open & 1.3 & 1.9 \\
\hline Manufacturing & 2.2 & NA & Conference & 1.5 & 1.8 \\
\hline Museum & 1.6 & NA & Training & 1.6 & 2.0 \\
\hline Office & 1.3 & 1.5 to 1.9 & Lobby & 1.8 & 1.9 \\
\hline Parking Garage & 0.3 & 0.2 to 0.3 & Lounge/Dining & 1.4 & 2.5 \\
\hline Retail & 1.9 & 2.1 to 3.3 & Food Prep & 2.2 & 1.4 \\
\hline School & 1.5 & 1.5 to 2.4 & Corridor & 0.7 & 0.8 \\
\hline & & & Restroom & 1.0 & 0.8 \\
\hline & & & Active Storage & 1.1 & 1.0 \\
\hline
\end{tabular}

NA: Not Available in the 1989 Edition

\subsection{State Characteristics}

The building simulation and LCC inputs of this study are characterized to fit statespecific characteristics such as climate, building construction trends, and energy source 
characteristics. The following sections explain some of the key components considered in tailoring the study to the state.

\subsubsection{Climate Zone}

The climate zone is defined by long-term weather conditions, which affect heating and cooling loads in buildings. The zones are based on annual average number of degreedays, which are a measure of how cold/hot a building location is relative to the base temperature ${ }^{1}$. The climate zones in Michigan range from 1421 cooling degree-days (CDD) and 9316 heating degree-days (HDD) in Sault Ste Marie (relatively cool climate zone located in the northern part of state) to 3399 CDD and 6416 HDD in Battle Creek.

\subsubsection{Demographic and Construction Data}

Michigan has a population of approximately 9.9 million. Although some of Michigan's population centers have experienced population declines in the past ten years (e.g., Detroit, Flint, and Lansing), several of the suburbs surrounding these centers have experienced significant growth. Livingston, St. Clair, and Washtenaw counties, which surround Detroit, Lansing, and Ann Arbor, have all experienced growth in the past ten years well above the state average. Grand Rapids and the surrounding suburbs, located in the southwest of the state, have also experienced significant growth (Census 2000b). In 1997 the value of new commercial construction in Michigan totaled \$6 billion. Office, retail, education, and food service buildings made over half the total value of new construction in that year (Census 2000c).

\subsubsection{Energy Consumption and Sources}

Michigan consumes approximately 3.2 quadrillion Btu of energy each year and approximately $30 \%$ of this energy is consumed by the commercial sector. The primary energy sources for building heating, cooling, and lighting in Michigan are gas and electricity. Coal power is the primary source of electricity generation in Michigan, making up over $60 \%$ of the total electric industry generation in 1999 (EIA 2001c).

\subsection{Assumptions}

Although Michigan has varying temperatures throughout the state, this analysis focuses on the southern region, where much of the population growth is occurring. Weather data representative of the climate in Michigan is taken from the Typical Meteorological Year (TMY) weather data set. The climate in southern Michigan, where the primary population and growth centers are located, is generally defined as having fewer than 3050 average annual CDD and 6000 to 7000 average annual HDD. The weather data for Detroit is used to simulate climate conditions in southern Michigan ${ }^{2}$.

\footnotetext{
${ }^{1}$ The daily heating degree days (HDD) is the numerical difference between a day's average temperature and 65 degrees Fahrenheit (HDD is zero if the day's average temperature is less than $65^{\circ} \mathrm{F}$ and the annual HDD is the sum of the daily HDD for the year. The daily cooling degree days (CDD) is the numerical difference between a day's average temperature and 50 degrees Fahrenheit (CDD is zero if the day's average temperature greater than $50{ }^{\circ} \mathrm{F}$ ) and annual CDD is the sum of the daily CDD for the year. 2 The weather in Detroit and Grand Rapids (the furthest populous city from Detroit) is similar and the Alternate Component Package (ACP) tables of the ASHRAE 90.1-1999 standard are the same.
} 
This study focuses on four different commercial building types: office, retail, education, and food-service/restaurant ${ }^{3}$. Eight building design prototypes are characterized and assessed. All buildings are characterized as rectangular buildings; however, they vary in size and window-to-wall ratios. A relatively small (1-story, 10,000 square foot) office building and a larger office building (3 floors, 60,000 square feet) are simulated and each size office is simulated with two separate window-to-wall ratios. Also, a 24,000 square foot, single-story retail building, 5,000 square foot restaurant, and two education buildings are characterized in this evaluation. A general description of all eight buildings analyzed is shown in Table 2 .

Table 2. Study Building Set

\begin{tabular}{|c|c|c|c|c|}
\hline $\begin{array}{l}\text { BUILDING } \\
\text { TYPE }\end{array}$ & $\begin{array}{l}\text { WINDOW-TO- } \\
\text { WALL RATIO }\end{array}$ & $\begin{array}{c}\text { SQUARE } \\
\text { FOOTAGE }\end{array}$ & $\begin{array}{c}\text { NUMBER OF } \\
\text { FLOORS }\end{array}$ & $\begin{array}{l}\text { ASPECT } \\
\text { RATIO }^{1} \\
\end{array}$ \\
\hline Small Office-1 & $18 \%$ & 10,000 & 1 & 2.25 \\
\hline Small Office-2 & $38 \%$ & 10,000 & 1 & 2.25 \\
\hline Large Office-3 & $18 \%$ & 60,000 & 3 & 2.25 \\
\hline Large Office-4 & $38 \%$ & 60,000 & 3 & 2.25 \\
\hline Retail & $7 \%$ & 24,000 & 1 & 2.5 \\
\hline $\begin{array}{l}\text { Education-1 } \\
\text { (Elementary) }\end{array}$ & $18 \%$ & 50,000 & 1 & 6 \\
\hline Education-2 & $18 \%$ & 80,000 & 2 & 5 \\
\hline Restaurant & $18 \%$ & 5,000 & 1 & 2.25 \\
\hline
\end{tabular}

It is assumed that these representative buildings are heated with a gas furnace and cooled with an electric air conditioner. It is assumed that all buildings are well operated (e.g., heating is setback when buildings are not occupied). When a building is operated well, the energy losses that would occur from heat leaving the building through relatively poorly insulated roofs, walls, and windows would be minimized. By assuming buildings are well-operated and heated with gas, the prototype buildings chosen in the study would represent the lower end of potential energy savings from envelope improvements.

The economic study period is set to be 40 years to adequately capture the changes in energy expenditures and replacement of key components over the (economic) life of the building. Costs and benefits are expressed in 2001 dollars, unless otherwise specified.

The envelope requirements for ASHRAE 90A-1980 are used as the baseline for the envelope analysis. The 90.1-1989 LPD requirements are used as the baseline for the lighting analysis. Although the costs and benefits of mechanical system under ASHRAE 90.1-1999 are not assessed in this report, all mechanical systems are assumed to satisfy the ASHRAE 90.1-1989 requirements within the building simulation model.

\footnotetext{
${ }^{3}$ For this analysis, the food service building is characterized as a family dining restaurant rather than bars/lounges or a fast-food style restaurant.
} 


\subsection{Energy Analysis}

Annual building energy use simulations were made using the BLAST program, developed by the Building Systems Laboratory of the University of Illinois. BLAST performs hourly energy simulations of buildings, air-handling systems, and central plant equipment.

\subsection{Simulation Process}

The BLAST output used for this analysis was based on a 3-story prototype building with 15 thermal zones. Each simulation has a given combination of ASHRAE 90A-1980, 90.1-1989, and 90.1-1999 standard levels for lighting, mechanical, and building envelope design. Each simulation provides annual Energy Use Intensity $\left(\mathrm{Btu} / \mathrm{ft}^{2}\right)$ for gas and electricity in each of the thermal zones. The Energy Use Intensities (EUIs) for each representative building type specified in Section 2.3 simulated in the Michigan climate were scaled to appropriately reflect variations in building size and shapes.

\subsection{Simulation Input Characterization}

\subsubsection{Building Envelope Inputs}

The building envelope characteristics examined in the analysis were the opaque wall and roof U-factors, the fenestration U-factors, either the fenestration Shading Coefficient requirements (in ASHRAE 90A-1980) or Solar Heat Gain Coefficient requirements (in the ASHRAE 90.1-1999), and the effective slab U-factors for slab on grade construction. These characteristics were determined for each set of requirement changes and building types. ASHRAE 90A-1980 uses several equations and figures to establish compliance of a commercial building's envelope. These figures represent the prescriptive compliance path for ASHRAE 90A-1980's envelope requirements. ASHRAE 90A-1980 specifies overall wall assembly U-factors to meet specified heating and cooling criteria. The actual U-factors of roofs, walls, and windows used in the simulations were chosen to reflect the U-factors of real building assemblies that must reach the required total wall assembly U-factors. This procedure provides a lower estimate of the envelope energy savings compared to a stricter requirement-to-requirement characterization of the wall U-factors.

\subsubsection{Lighting Inputs}

The lighting power density requirements were developed from the whole building lighting requirements for both ASHRAE 90.1-1989 and ASHRAE 90.1-1999 for comparable building types. The 90.1-1999 standard provides single value whole building lighting power density values for thirty-one different building types while the 90.1-1989 standard provides values for only eleven. ASHRAE 90.1-1989 also provides different lighting power densities for six different building size categories within each building type.

The whole building LPD values for 90.1-1989 do not correspond perfectly to the building types simulated. In order to develop whole building lighting numbers for each building type, a weighting process was employed based on the Commercial Buildings Energy 
Consumption Survey (CBECS) data (1995). In the case of education, for example, ASHRAE 90.1-1989 provides LPD values for subcategories (preschool/elementary, Jr. High/High School, and Technical/Vocational school) of this building type. With education buildings, the LPDs are first averaged for each building type category and then the resulting LPDs are weighted by building size. In the case of retail type buildings, ASHRAE 90.1-1989 has three basic retail building subcategories (retail, mall concourse, and service). A weighted average of the allowed LPDs was constructed, using ASHRAE 90.1-1989's LPD values and the CBECS 95 floor area data for each building type and size category.

ASHRAE 90.1-1999 provides single value, whole building, LPD requirements for office, retail, and education buildings, and these requirements were used in the simulations. Table 3 shows a comparison of the Whole Building lighting requirements under both editions.

Table 3. Lighting Power Density (Watts/sq. ft)

\begin{tabular}{|l|c|c|}
\hline Building Type & $\mathbf{9 0 . 1 - 1 9 8 9}$ & $\mathbf{9 0 . 1 - 1 9 9 9}$ \\
\hline Education & 1.79 & 1.50 \\
Offices & 1.63 & 1.30 \\
Retail & 2.36 & 1.90 \\
\hline
\end{tabular}

\subsubsection{Mechanical Inputs}

Although mechanical equipment is not included in the scope of this economic analysis, some energy simulation results for the average national impact of this requirement are available. DOEs overall comparison of the improvements in mechanical system efficiencies between ASHRAE 90.1-1989 and 90.1-1999 results in a 2.2\% efficiency improvement in Site Electric EUI and 3\% efficiency improvement in Gas EUI ${ }^{4}$.

\section{Heating}

There is relatively little improvement in heating equipment efficiency requirements in ASHRAE 90.1-1999 for equipment used in single zones systems (typically furnaces). It was found that the impact of ASHRAE 90.1-1999 on heating energy use would principally be determined by changes in heating loads rather than equipment efficiency.

\section{Cooling}

In the case of cooling equipment, the average efficiency of cooling equipment, based on shipped capacity increased $7.5 \%$.

\section{Service Water Heating}

Service water heating equipment efficiencies increased from $78 \%$ to $80 \%$ for most tanktype gas fired water heaters.

\footnotetext{
${ }^{4}$ The national simulation results for the Department of Energy's Determination regarding whether ASHRAE 90.1-1999 would improve energy efficiency in new commercial buildings are also found on the Building Standards and Guidelines website (http://www.energycodes.gov/implement/determinations_com.stm).
} 


\subsection{Economic Analysis}

The economic benefit and cost analysis of adopting 90.1-1999 utilizes the life cycle cost (LCC) approach, which compares the monetary savings over a specified time horizon with comparison to the associated costs of complying with the code. For this study the LCC is a general measure of the cost of operating a building over its assumed 40-year lifetime and includes the initial incremental construction cost, replacement of key components, and annual energy expenditures. A key assumption in the valuation of future benefits and costs is the time value of money or discount rate that reflects the opportunity cost of capital.

Several factors influence the cost and savings from adopting an energy efficiency building code -first costs, replacement costs, maintenance costs, and energy savings. The primary costs associated with code adoption are the incremental costs of required materials and installation that will contribute to reduced annual energy consumption (e.g., higher levels of insulation, more efficient light fixtures) relative to the cost of building materials that would satisfy a less stringent set of requirements. These costs are often referred to as "first costs," as they are incurred when the building is first built. The collection and treatment of first costs for lighting and building envelope materials is discussed in the following sections. In addition to the first costs, many components will need to be replaced during the 40-year period assumed in this study. The sum of the first cost and the replacement cost is referred to as total investment cost. A comparison of ongoing maintenance costs (excluding replacement costs) for various types of equipment and materials is not included in this analysis (i.e. it can be interpreted that maintenance costs are assumed to be the same for 90.1-1999 and 90.1-1989 requirements).

The primary ongoing monetary benefit of the code is the energy that is saved over the life of a building by using relatively more energy efficient designs, materials and equipment. The incremental energy savings are valued using forecasted average commercial gas and electricity rates over a specified time horizon. These future values of replacement costs and energy savings are then discounted to a present value. This study uses a constant $7 \%$ (real) discount rate, which is consistent with the value used by U.S. Department of Energy in analyses of residential and commercial equipment efficiency standards 5 .

The current average gas and electricity prices for Michigan were obtained from the Energy Information Administration (EIA) and are listed in Table 4 (2001a). Based on the Annual Energy Outlook 2002 forecasts (EIA 2001b) ${ }^{6}$ the average fuel rates are escalated

\footnotetext{
${ }^{5}$ This particular value is motivated by the recommendation of the Office of Management and Budget (OMB) in Circular A-94, (OMB1992). Circular A-94 indicates that this value corresponds to the approximate marginal pretax rate of return on the average investment in the private sector in recent years. All rates are reported as "real" rates, which refers to the discount rate above any nominal inflation rate.

${ }^{6}$ During 2001 gas prices spiked throughout the U.S. In order to avoid this atypical spike in the analysis, the gas rates from the year 2000 are used in place of the elevated 2001 rates, and the bubble was removed from the escalation rates for 2002 through 2005.
} 
throughout the first 20-years of the study period and are assumed to remain flat the remaining 20 years of the study period ${ }^{7}$.

Table 4. Commercial Average Annual Fuel Rates in Michigan

\begin{tabular}{||c||c||}
\hline $\begin{array}{c}\text { Average Annual Price of } \\
\text { Natural Gas } \\
(2000)\end{array}$ & $\begin{array}{c}\text { Average Annual Price of } \\
\text { Electricity } \\
(2000)\end{array}$ \\
\hline \hline \\
$\$ 4.8 /$ thousand cubic feet
\end{tabular}

The economic impacts are calculated using a spreadsheet-based LCC model that compares alternative sets of building technologies corresponding to different building standards. The model borrows elements of the Building Life-Cycle Cost Program (BLCC) produced by the National Institute of Standards and Technology (NIST) and DOE Federal Energy Management Program (FEMP) ${ }^{8}$.

\subsection{Building Envelope Analysis}

The costs for various building envelope materials are derived on a square footage basis. Costs for walls, roofs, and floors are dependent on the type of construction (e.g., masonry wall versus frame or flat built-up roof versus pitched roof with attic) and vary by Ufactors. Discrete costs for various assembly types are based on cost estimates gathered during the development of the 90.1-1999 standard by the ASHRAE envelope subcommittee. Costs for windows and glazing materials were gathered and compiled by Charles Eley Associates. Although costs were collected from 1994-1997, all costs are inflated to 2001 by using price indexes from the Producer Price Index for specific building materials (BLS, 2002).

The building envelope costs are measured and reported as incremental costs to achieve a certain level of thermal integrity (U-factor). For the roof and opaque walls, the costs are estimated relative to a base wall and roof assembly containing no insulation. The window costs measure the incremental costs of glazing that has a specific U-factor and shading coefficient, as compared to a window with a single pane of clear glass.

For all envelope components, the spreadsheet model estimates the incremental costs per square foot for alternative levels of standards. The incremental costs per square foot are multiplied by the appropriate area (roof, walls, windows) to generate the total incremental building envelope cost. The envelope first costs, therefore, do not reflect the total cost of constructing roofs, walls, and windows.

\footnotetext{
${ }^{7}$ The average annual escalation was $-.2 \%$ for electricity rates and $.2 \%$ for gas rates.

${ }^{8}$ Portions of a spreadsheet version of the BLCC, developed by M.S. Addison and Associates (Tempe, AZ) were adapted for use in the more extensive LCC model used for this study.
} 


\subsection{Lighting Analysis}

There are numerous advantages to integrating flexibility into the ASHRAE 90.1 standards for the purpose of enabling consumers to choose lighting options appropriate for their situations. This flexibility, however, makes evaluating the economic impacts quite challenging because there are alternative ways to comply with the standard. Although a variety of alternatives may result in similar energy use outcomes, each alternative has its own distinct cost implication.

In order to assess the economic impacts of lighting code changes between ASHRAE 90.1-1989 and 90.1-1999, the factors impacting lighting design choices must be considered. Some of the primary lighting design choices affecting application of lighting technology in buildings include the following:

- Luminance Level - this varies based on the needs of the space, including task requirements, occupants, and overall desired atmosphere of the environment. This is general driven by recommendations made by the Illuminating Engineering Society (IES).

- Lighting Technology Type (e.g, incandescent, fluorescent, high intensity discharge (HID), and ballast choices)

- Light Distribution Technology Type (e.g., lenses, louvers, reflective luminaries, and reflective materials).

It is likely that a lighting design change based on the stricter requirements of 90.1-1999 would primarily involve technology changes only. Other potential methods of complying with a new code would include simple lighting level reduction and/or total redesign of the space using advanced lighting techniques. Total redesign of the space, however, is considered to be uncommon in practice and will not be considered in this analysis.

Each space (e.g., office, hallway, sales area etc.) within each building type in the ASHRAE 90.1-1999 Whole Building Space Data Allocations is associated with up to three different lighting types with each type representing a lighting technology and associated fixture9. The amount of light specified for each space (determined by IES recommendations and ASHRAE sub-committee input) is further allocated to each of these (up to three) lighting types. Each of these types is also further defined by an efficacy of the technology (lumens per watt) and standard adjustment factors (lumen depreciation, room surface, etc.).

The set of space type allocations listed in the ASHRAE 90.1-1999 Space Type Models provide one method of meeting the requirements of the standard. These models, based on actual designer and experience input, are considered the most accurate and detailed of their kind available for providing efficient and effective lighting. The models also serve as the basis for comparison with other standards or current practice scenarios.

\footnotetext{
${ }^{9}$ For example, the three lighting types for an office conference room include linear fluorescent, wall wash fluorescent, and halogen down lights.
} 
The approach used to evaluate lighting benefits utilizes lighting costs for systems of lighting, which include the lamp, fixture, and ballast combination. First, the ASHRAE Space Models are applied to the spaces in each building type to determine the lighting system that meets the standard at the lowest cost. The power densities and costs are then developed for each space and lighting system, and aggregated up to the whole building level for the analysis

The assignment of differences in power densities between the 1999 standard and the 1989 standard can be evaluated as either differences in light level or the efficacy of lighting technologies (or both). Some assumptions are made to permit a reasonable assessment of the actual difference in design to meet the two standards and allow a comparison of energy consumption and costs. Because of the vast variance in lighting design, it is impractical to assign too much detail to a scenario; however, many common space types within buildings exhibit some common lighting design attributes. Some examples are included in Table 5.

Table 5. Selected Examples of Building Spaces and Corresponding Common Lighting Designs

\begin{tabular}{|l|l|}
\hline Space Type & Lighting Design Characteristics \\
\hline Typical open office areas & $\begin{array}{l}\text { Evenly spaced fluorescent troffers with little decorative } \\
\text { lighting }\end{array}$ \\
\hline Typical enclosed offices & Fluorescent troffers \\
\hline Hallways/lobbies & Fluorescent troffers and incandescent downlights \\
\hline Large Retail spaces & $\begin{array}{l}\text { Overhead fluorescent troffers and incandescent display } \\
\text { lights }\end{array}$ \\
\hline
\end{tabular}

Since the lighting requirements for the 90.1-1999 standard are well defined through the use of the space type models as described above, the development of capital costs for lighting meeting the 1989 standard is based upon a substitution of less efficient technologies than those used to comply with the 1999 standard. The substitution involves two types of lighting systems:

1) Magnetic ballast-T12 lamps for electronic ballast-T8 lamps

2) Incandescent lamps for compact fluorescent lamps in downlight applications.

These substitutions were made for all the space types used in the ASHRAE methodology underlying the development of the 1999 lighting standard. ${ }^{10}$ The 90.1-1999 wholebuilding LPD will increase by different percentage amounts over 90.1-1989, depending upon the assumed fractions of floor space to be served by the technologies in each of the building types.

\footnotetext{
${ }^{10}$ The methodology for the space type and LPD models is incorporated in a large spreadsheet that was developed by the lighting subcommittee of the SSPC 90.1 ASHRAE standards committee in support of the ASHRAE/IESNA 90.1-1999 energy standard. A working version of the spreadsheet tool with additional detailed descriptions of the various parts is available for review on the IESNA website (http://206.55.31.90/cgi-bin/lpd/lpdhome.pl). An offline version of the spreadsheet was modified in three ways: 1) technologies for magnetic ballasts and T-12 lamps were added, 2) a series of worksheets to estimate lighting system costs was added, and 3) a revised formula (consistent with the most recent ASHRAE/IES work) was used in the calculation of LPDs.
} 
The first two columns of Table 6 show the building-level LPDs that were used in the economic analysis. Column 3 displays the efficiency improvement in the LPD between the 1999 and 1989 standard. Column 4 shows the increase from the 1999 standard brought about solely by the technology substitution discussed above. For office and education buildings, the technology substitution (as described in numbers (1) and (2) above) results in an increase in the LPD that is very close to the requirements of the 1989 standard.

Table 6. Comparison of 90.1-1999 and 90.1-1989 Lighting power Densities

\begin{tabular}{|l|l|l|l|l|}
\hline & $1999 \mathrm{LPD}^{*}$ & $1989 \mathrm{LPD} *$ & $\begin{array}{l}\text { Percent } \\
\text { Change }\end{array}$ & $\begin{array}{l}\text { Technology } \\
\text { Substitution } \\
\text { (Percent } \\
\text { Change) }\end{array}$ \\
\hline Office & $1.30 \mathrm{w} / \mathrm{ft}^{2}$ & $1.63 \mathrm{w} / \mathrm{ft}^{2}$ & $25.4 \%$ & $24.0 \%$ \\
\hline Retail & $1.9 \mathrm{w} / \mathrm{ft}^{2}$ & $2.36 \mathrm{w} / \mathrm{ft}^{2}$ & $24.2 \%$ & $16.0 \%$ \\
\hline Education & $1.5 \mathrm{w} / \mathrm{ft}^{2}$ & $1.79 \mathrm{w} / \mathrm{ft}^{2}$ & $19.3 \%$ & $20.8 \%$ \\
\hline
\end{tabular}

As used in the building energy simulations and economic analysis.

As a first step, cost estimates were developed for the linear fluorescent and incandescent/CFL applications for both the 90.1-1999 standard based upon the ASHRAE Models. The less efficient technologies associated with the 90.1-1989 standard levels were substituted into the same models (i.e., assuming the same illumination levels) to determine a corresponding increase in predicted LPD. A ratio was computed between the reduction in cost and the increase in the predicted LPD, going from the more efficient to the less efficient lighting technologies (the change in predicted LPD is equal to the percentage change in column 4 in Table 6 times the 1999 LPD in column 1). This ratio was then applied to the actual difference in the LPD between the two standards to make an estimate the change in cost.

For office and education buildings, this procedure yields essentially the same cost difference as that generated by the technology substitution without any adjustment. Since the predicted change in the LPD for retail buildings was lower than the actual difference ( $16 \%$ vs. $24 \%$ in Table 6 ), this procedure provides an upper bound to the cost difference (and, concomitantly, a conservative estimate of the life-cycle cost reduction) between the two standards for this building type. A further calibration was performed to account for a revision in the way in which the LPDs were calculated in the ASHRAE Models for this study as compared to how these models were employed when developing the current published standard. ${ }^{11}$

Lighting costs are measured in terms of total lighting cost in dollars per square foot for linear fluorescent and incandescent/CFL systems. These costs include the cost of a

\footnotetext{
${ }^{11}$ The use of the revised formula in the LPD spreadsheet (see previous footnote) causes the calculated 90.11999 LPDs to be higher than those published for the 1999 standard. The calculated LPDs were: 1) office, 1.40 watts $/ \mathrm{ft}^{2} ; 2$ ) retail, 2.14 watts $/ \mathrm{ft}^{2}$, and 3) education 1.54 watts/ $\mathrm{ft}^{2}$. The revised formula ensures that the economic benefits from a technology substitution are consistent across building types. Unfortunately, it requires that the cost calibration must be performed on the basis of percentage changes rather than the absolute levels of the LPDs.
} 
fixture, ballast, and lamp plus the labor cost to install the assembly. The linear fluorescent lighting cost estimates are based on data from the Technical Support Document (TSD) for the DOE's rulemaking related to fluorescent lamp ballasts (DOE 1999). For compact fluorescent and incandescent systems, data were developed from the input data used in the commercial module of the National Energy Modeling System (NEMS) and from a PNNL analysis of contractor prices from Grainger Industrial Supply. Although the lighting cost may vary for any particular building due to the type of lighting technology used, the above derivations are representative of the cost differentials. 


\subsection{Quantitative Results}

The incremental changes in energy use going from the baseline to ASHRAE 90.1-1999 are calculated in terms of energy use intensities (EUI) developed from simulations based on each edition of the new standard. The simulations produce EUIs by fuel type for each zone of the prototypical building. These results are then scaled to the building type of interest. The zone EUIs by fuel type can be converted to site energy, source energy, and energy cost intensities, by building type. Specific building simulation inputs and resulting energy savings for particular building types included in this study are found in Appendix $\mathrm{B}^{12}$.

This section presents the estimated energy and economic impacts between the ASHRAE 90A-1980 and ASHRAE 90.1-1999 building standards for the selected set of buildings. Three separate variations of the 1999 standard are compared with the baseline: 1) Changing only requirements related to the building envelope; 2) Changing only lighting requirements; and 3) Changing both envelope and lighting requirements. This methodology helps to better understand how the energy and economic impacts are linked to various aspects of the standards. The combined lighting and envelope case shows the degree to which interaction between the envelope and lights affect the overall impacts.

\subsection{Office Buildings}

Four different types of office buildings are characterized in this study. The different office buildings are designed to capture the variation of the standard's impacts that stem from alternative window-to-wall ratios, building size, and number of floors. All of the office buildings are characterized as having metal frame walls.

Table 6 presents the engineering and cost summary for the small, 10,000 square foot, single-story office building. The top panel of the table shows the key engineering and cost inputs for the building envelope. Based upon a building height of 13 feet, and an aspect ratio of 2.25 (ratio of building length to width), the total wall area of the building is 5,733 square feet. Given the assumed window-to-wall ratio of 0.18 , this translates into 1,013 square feet of windows and 4,619 square feet of opaque wall. In a building with a single floor, the roof area is equal to the floor area. The insulation requirements for the slab are related to the perimeter length. For this building, the perimeter of the building is 433 feet. Figure 1 provides an illustration of an office building that has these characteristics.

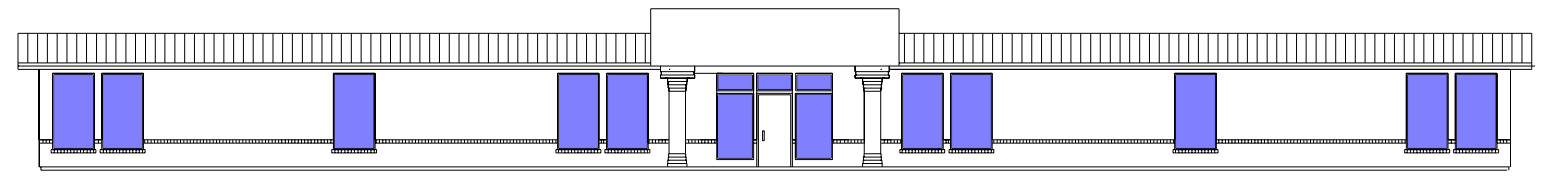

Figure 1. Office Building - 20,000 s.f. with 18\% window-to-wall ratio

\footnotetext{
${ }^{12}$ The national simulation results for the U.S. Department of Energy's Determination regarding whether ASHRAE 90.1-1999 would improve energy efficiency in new commercial buildings are also found on the Building Standards and Guidelines website (http://www.energycodes.gov/implement/determinations_com.stm).
} 


\section{Base Case}

The column under the heading "90A-1980 Base" shows the thermal requirements and estimated costs for each of the major envelope components. Windows must satisfy requirements related to both thermal performance (U-factor) and shading coefficient (SC). The specific requirements under the 1980 (and 1989 for lighting) standard are designated in the top two lines labeled (std). The current costing methodology for windows generally selects the window type that meets the performance requirements of the standard at the lowest cost. To avoid potential distortions in the incremental cost from one standard level to the next, an algorithm was developed that essentially searches for the pair of glazing types in the cost database that are just below and just above the U-factor and SC criteria. The costs and performance measures are then averaged with a weighting procedure, the weights based upon how much each type deviates from the criteria. The weighted averaged U-factor and shading coefficient are labeled (cost) in the table. Using the weighting procedure, a representative cost per square foot of glazing was estimated to be $\$ 4.60$.

Costs for the other envelope components are based upon the cost model developed as part of the ASHRAE Standard 90.1-1999. The total cost for each component is simply the product of the area and the cost per square foot (or linear foot for slab insulation) to achieve the specified thermal performance. Total cost is shown in the last line of the first panel-in this case $\$ 17,331$. As discussed in Section 4.1 above, this is not the total cost of the building envelope from an owner's point of view. It is, rather, the incremental cost relative to an uninsulated building using single-pane clear glass windows.

The second panel in Table 6 summarizes the key inputs related to lighting. As discussed in Section 4, the lighting power density for offices under the 1989 standard was assumed to be 1.63 watts per square foot. The first cost of the linear fluorescent and incandescent systems to meet this lighting density is estimated to be $\$ 1.57$ per square foot. In the same manner as the envelope, this cost figure should not be construed as the total cost to install all the lighting in a typical office building. It includes only linear fluorescent and a segment of incandescent lighting that are assumed to change under the more stringent 1999 standard. Given this qualification, the lighting cost for the building is $\$ 15,720$.

The bottom panel in the table shows the energy and cost implications for the entire building. The initial construction cost is the sum of the envelope and lighting costs, keeping in mind the incremental nature of this value. Annual energy consumption is shown in million Btu (MMBtu) for electricity and natural gas. Electricity consumption is shown for 1) lights and plugs and 2) HVAC. In these simulations, all buildings were assumed to be heated with natural gas. Electricity consumed for HVAC equipment, therefore, consists of ventilation fan and cooling use only. Natural gas is used for space heating and water heating, but differences among standards are entirely related to space heating. Total annual energy cost of $\$ 9,658$ is based upon fuel prices for $2001^{13}$. The fuel prices used in this calculation are shown in note (2) at the bottom of the table.

${ }^{13}$ As discussed in Section 4.0, 2000 fuel prices were used for 2001. See footnote 3 in Section 4.0. Converted to dollars per MMBtu, the electricity price is $\$ 20.83$ and the natural gas price is $\$ 4.67$. 
Table 7. Engineering and Cost Summary

Small Office $(W W R=0.18)$

Bldg. Size $\quad \mathbf{1 0 , 0 0 0}$ sq. ft.

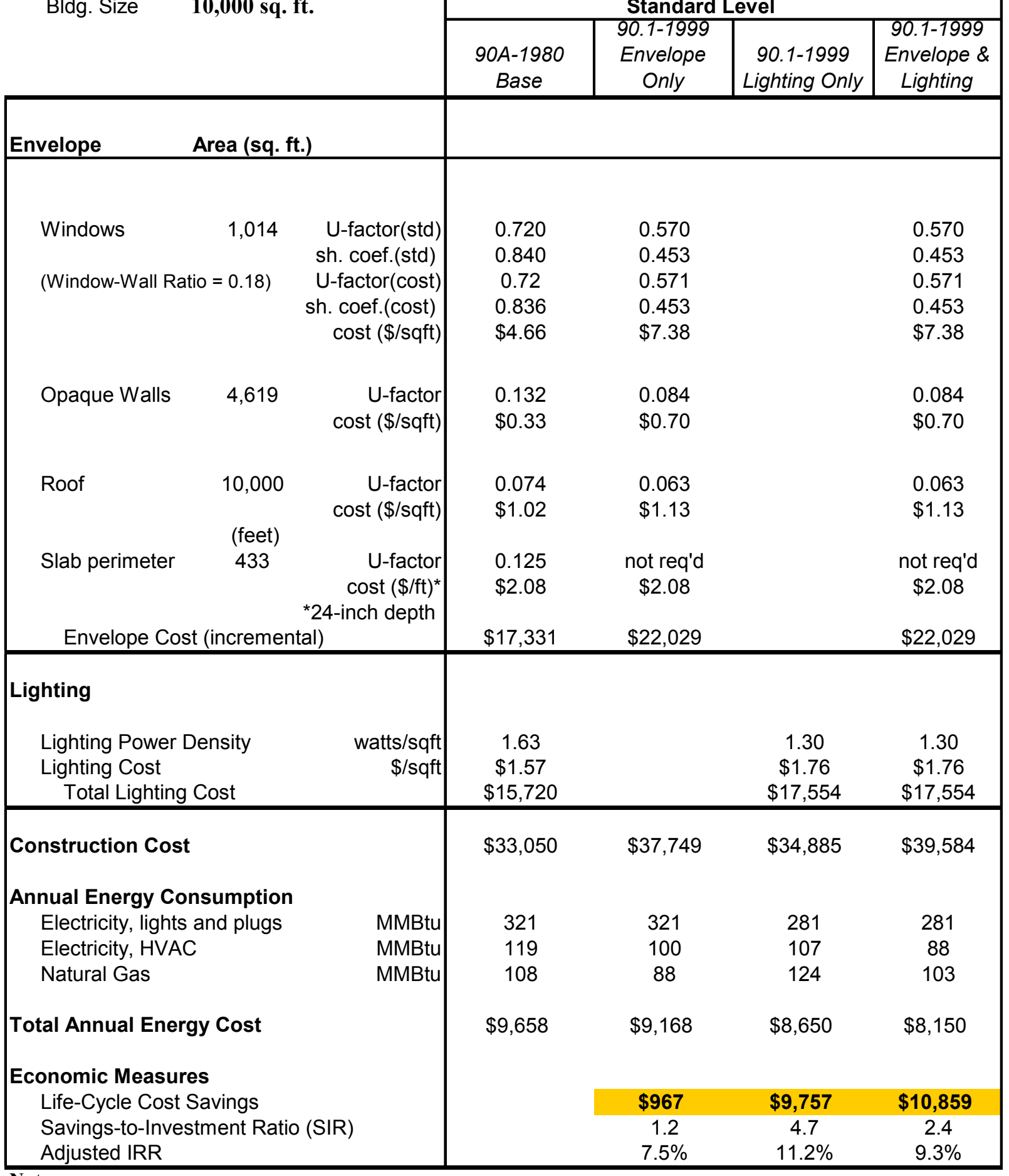

Notes:

1 No economizer used

22001 electricity price $=7.1$ cents $/ \mathbf{k W h}$

2001 gas price $=\$ 4.67 / \mathrm{MMBtu}$

3 Years for Analysis $=40$

Discount Rate $=\mathbf{7 . 0} \%$

Life-cycle cost savings includes replacement costs and residual values 
The second column under the section labeled "Standard Level" shows the envelope requirements and the estimated costs for standard ASHRAE 90.1-1999. For windows, both the U-factor and shading coefficient are significantly reduced. The reduction in the U-factor and shading coefficient is estimated to increase the initial cost relative to the 1980 requirements by about $\$ 2.72$ per square foot of window area. Wall and roof factors are also reduced and increase first costs by $\$ .37$ per square foot for walls and $\$ .11$ per square foot for roofs.

The ASHRAE 90.1-1999 standard dropped the requirement to insulate the slab foundation. This change contributed to a $\$ 900$ reduction to the first costs. The bottom line of the envelope panel shows a net increase in first costs of about $\$ 4,700$ from the 1980 standard level.

The bottom panel shows the energy consumption and cost impacts associated with this case. Electricity consumption for lights and plugs is unchanged from the baseline case. Electricity consumption for cooling and ventilation and natural gas consumption for heating fall by 19 MMBtu and $20 \mathrm{MMBtu}$, respectively, a result achieved from improvements in wall and roof insulation and reduced solar gain through the windows. Annual fuel costs decline by nearly $\$ 500$ a year.

Life-cycle costs are about \$1,000 lower as compared to the base ASHRAE 90A-1980. The cost savings are the sum of the $\$ 4,700$ initial construction cost reduction as well as the discounted energy cost savings over the 40 -year study period. The savings-toinvestment (SIR) ratio is 1.2 and the adjusted internal rate of return (AIRR) ${ }^{14}$ is $7.5 \%$.

In the lighting-only case, the approach described in Section 4.2 yields an incremental cost of $\$ 0.19$ per square foot as shown in column three of the lighting panel. The total incremental cost for the building is about $\$ 1,800$. Total electricity consumption falls by 52 MMBtu per year for the lighting-only case. Nearly one-fourth of this reduction stems from the lower cooling requirements because the efficient lights generate less heat. During the winter, less heat generated by the efficient lights means more heating by the furnace; thus, natural gas consumption increases. However, the reduction in cooling cost is larger than the increase in heating cost. Combined with reduced electricity use for the lighting, total fuel costs decline by over $\$ 1,000$ per year.

All three economic measures show that the more stringent lighting requirements associated with the 1999 standards are highly cost effective. Life-cycle cost savings are nearly $\$ 10,000$. The savings-to-investment ratio is over 4.7. In other words, for every dollar of initial and (discounted) replacement investment cost, nearly 5 dollars of

\footnotetext{
${ }^{14}$ In this type of analysis, the internal rate of return (IRR) is the interest rate that makes the discounted (present) value of the initial and replacement investment equal to the discounted value of future fuel cost savings. The adjusted internal rate of return (AIRR) can be considered an improved measure of investment performance. The AIRR assumes that the annual cost savings are reinvested at a fixed discount rate, rather than at the internal rate. The AIRR is generated by the NIST Building Life-Cycle Cost model.
} 
(discounted) fuel expenditures are saved over the life of the building. The adjusted internal rate of return is over $11 \%{ }^{15}$

The last column in the tables shows the results of a simulation that combines both the envelope and lighting requirements of the ASHRAE 90.1-1999 standard. Annual energy expenditures are about $\$ 1,500$ lower than the base ASHRAE 90A-1980 standard; lifecycle cost savings are nearly $\$ 11,000$. The net effect of the envelope and lighting energy savings and first cost increases is to yield an SIR of nearly 2.4 and adjusted IRR of $9 \%$.

\subsubsection{Impact of Changing Window-to-Wall Ratios}

Table 8 shows the results for a small office, but with a larger percentage (38\% vs. $18 \%$ ) of the wall area made up of windows. Figure 2 shows a 20,000 square foot office building with $38 \%$ of the walls made up of windows. Because standard 90A-1980 sets the requirements for total wall assemblies, the buildings with relatively higher windowto-wall ratios have relatively more stringent window performance requirements.

Therefore, there is very little change from the ASHRAE 90A-1980 window requirements to the ASHRAE 90.1-1999 window requirements for these buildings with higher window-to-wall ratios.

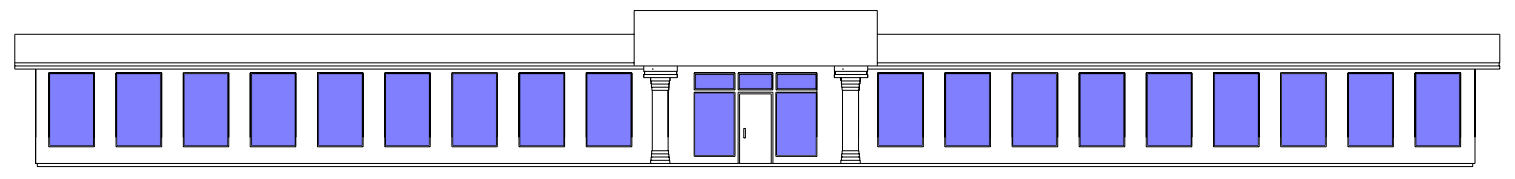

Figure 2. Office - 20,000 s.f. with 38\% window-to-wall ratio

In this envelope-only case, there is a reduction in wall and roof U-factors using 90.11999, but window U-factors remain the same. There is a slight decline, however, in the shading coefficient requirements going from 90A-1980 to 90.1-1999. As expected, the lower shading coefficient and envelope component U-factors lead to lower electricity use for cooling; however, the lower shading coefficient reduces solar gains through the windows (combined with the elimination of the slab insulation requirements) and results in slightly higher heating requirements.

\footnotetext{
15 The difference between the IRR and AIRR can be considerable. In this case the IRR is over $50 \%$. The AIRR measure is more suitable for long-lived investments with its assumption that cost savings can be reinvested to achieve only a normal return over a long period of time. Another short-term measure is the payback period. In this case the payback is less than 2 years $(\$ 1,800 / \$ 1,000)$. The payback criterion is also not especially appropriate, however, for investments with a long life - those appropriate to the life-cycle of a building — as it ignores the benefits after the payback period.
} 
Table 8. Engineering and Cost Summary

\section{Small Office (WWR=0.38)}

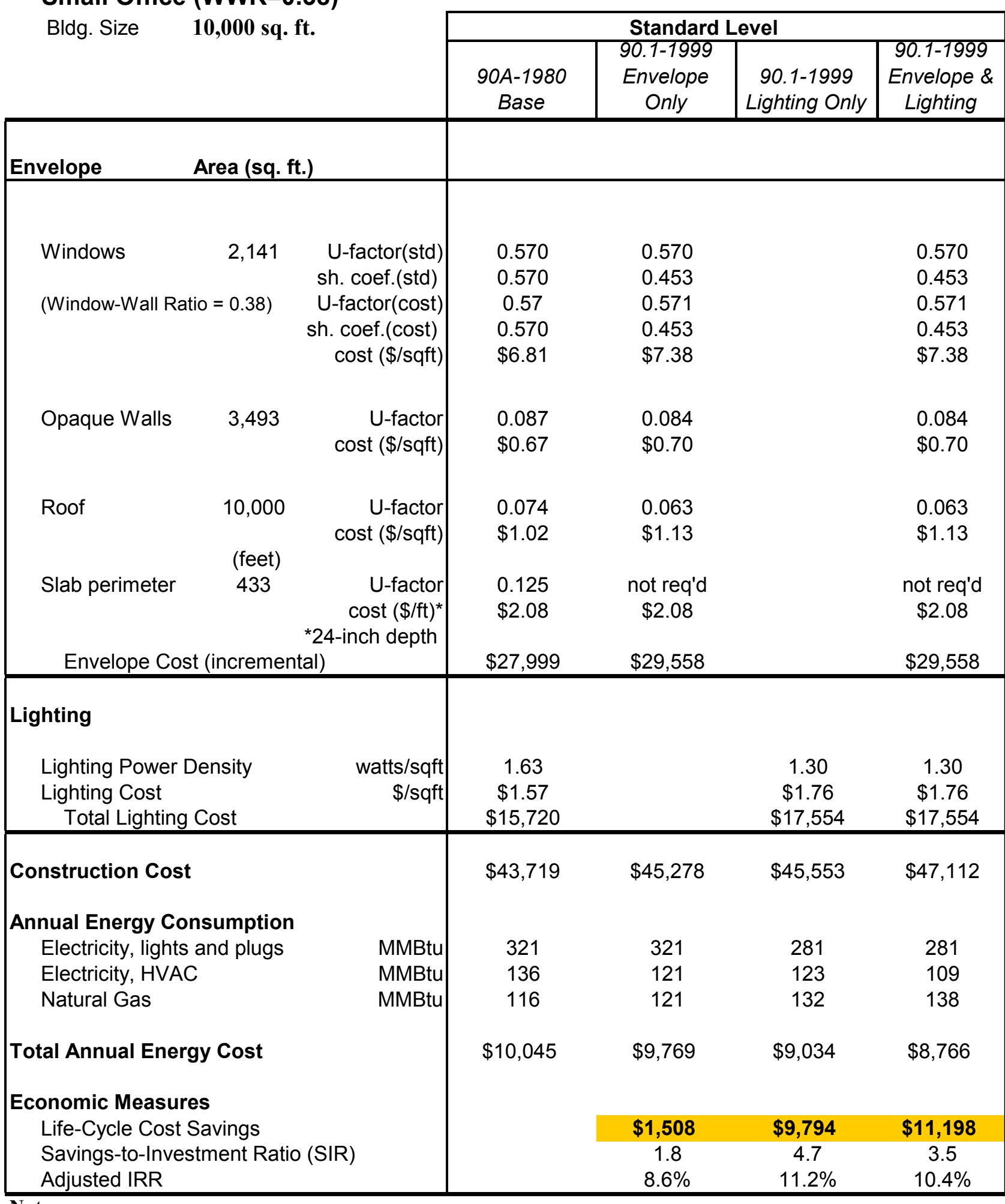

Notes:

1 No economizer used

22001 electricity price $=7.1$ cents $/ \mathbf{k W h} \quad 2001$ gas price $=\$ 4.67 / \mathrm{MMBtu}$

3 Years for Analysis $=40 \quad$ Discount Rate $=\mathbf{7 . 0 \%}$

Life-cycle cost savings includes replacement costs and residual values 


\subsubsection{Impact of Changing Building Size}

The large office building analyzed has a larger footprint (20,000 square feet as compared to 10,000 square feet) and has three floors. Figure 3 illustrates an office building with these characteristics. Because it is assumed to use cooling equipment with a large capacity, it is modeled with an economizer. An economizer utilizes outside air for cooling once the temperature falls below a thermostat set point. Similar to the small office, two variations in the window-to-wall ratio (18\% and 38\%) were considered.

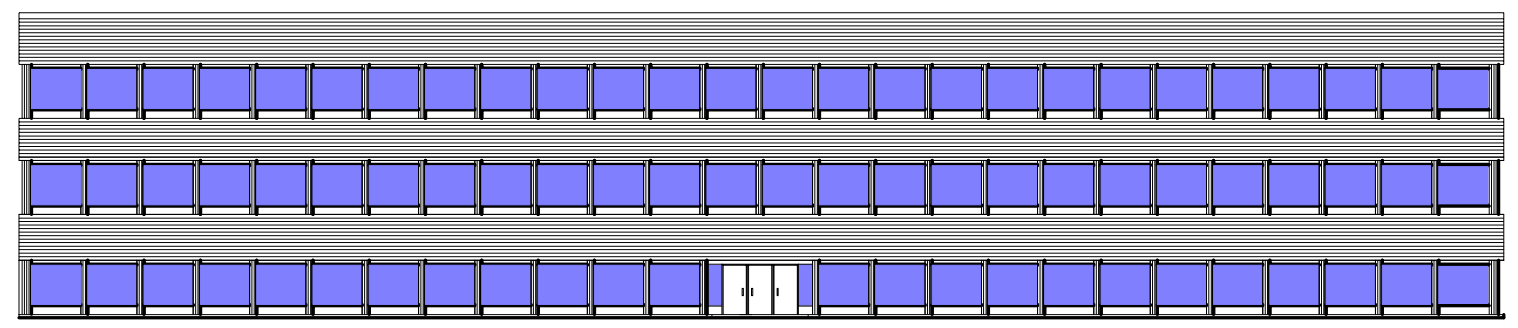

Figure 3. Office-60,000 s.f. with 3 stories and 38\% window-to-wall ratio

Tables similar to those presented for the small office are shown in Appendix A. The envelope and lighting requirements for the various cases are identical to those for the small office. Differences in the small and large office relate more to how the building geometry affects the envelope costs in total.

Table 9 shows a comparison of the key results for the four office building simulations. The top two panels show the results for the small office buildings for the .18 and .38 window-wall ratios, and the bottom two panels show the same for the large office building. The "Key Characteristics" column shows the physical characteristics of the building that have the most significant impact on its energy use with the only difference in the two cases (small and large office) being the window-wall ratio. ${ }^{16}$ The three columns on the right hand side of the table provide the cost results of the savings relative to the 90.1-1989 base on a per square-foot basis for the envelope only, lighting only, and combined envelope and lighting improvements.

Life-cycle cost is the discounted energy savings minus the discounted incremental cost of 90.1-1999 over the 40-year lifetime of the building. Two metrics, the savings-toinvestment ratio (SIR) and the internal-rate-of-return (IRR) are also shown to provide a measure of the financial attractiveness of the standard from an investment perspective.

\footnotetext{
${ }^{16}$ The BLAST simulations used a 15 -foot depth to represent the perimeter zones of the building. The interior floor space of the building is the core; the core ratio shown in Table 8 is the ratio of the core to the total floor area. It provides one means of assessing how much the wall and window components influence the overall energy use in the building.
} 
Table 9. Summary of Results for Office Buildings

\begin{tabular}{|c|c|c|c|c|c|c|}
\hline \multirow[t]{2}{*}{ Location: } & \multicolumn{2}{|c|}{ Michigan } & \multicolumn{4}{|c|}{ Standard Level } \\
\hline & & & $\begin{array}{l}\text { 90.1-1989 } \\
\text { Base }\end{array}$ & $\begin{array}{c}90.1-1999 \\
\text { Envelope } \\
\text { Only }\end{array}$ & $\begin{array}{c}90.1- \\
1999 \\
\text { Lighting } \\
\text { Only }\end{array}$ & $\begin{array}{l}\text { 90.1-1999 } \\
\text { Envelope } \\
\text { \& Lighting }\end{array}$ \\
\hline \multicolumn{2}{|c|}{ Small Office (WWR=0.18) } & Normalized Results & Base & \multicolumn{3}{|c|}{ Savings Relative to Base } \\
\hline \multicolumn{2}{|c|}{ Key Characteristics } & Energy Use: & \multirow{7}{*}{$\begin{array}{c}44.0 \\
10.8 \\
\$ 0.97\end{array}$} & \multirow[b]{2}{*}{1.9} & \multirow[b]{2}{*}{5.2} & \multirow[b]{2}{*}{7.1} \\
\hline Floor space & 10,000 & Electricity (kBtu/sqft/yr) & & & & \\
\hline No. of floors & 1 & Nat. Gas (kBtu/sqft/yr) & & 2.0 & -1.6 & 0.5 \\
\hline Aspect ratio & 2.25 & Energy cost $\quad(\$ / \mathrm{sqft} / \mathrm{yr})$ & & $\$ 0.05$ & $\$ 0.10$ & $\$ 0.15$ \\
\hline Core ratio & 0.44 & Life-cycle cost $\quad(\$ /$ sqft $)$ & & $\$ 0.10$ & $\$ 0.98$ & $\$ 1.09$ \\
\hline \multirow{2}{*}{$\begin{array}{l}\text { Window-wall ratio } \\
\text { Economizer (?) }\end{array}$} & 0.18 & & & \multirow[b]{2}{*}{$\begin{array}{c}1.2 \\
7.5 \%\end{array}$} & & \multirow[b]{2}{*}{$\begin{array}{c}2.4 \\
9.3 \%\end{array}$} \\
\hline & no & $\begin{array}{r}\text { Savings-to-invest. Ratio } \\
\text { Adjusted IRR }\end{array}$ & & & $\begin{array}{c}4.7 \\
11.2 \%\end{array}$ & \\
\hline \multicolumn{2}{|c|}{ Small Office (WWR=0.38) } & Normalized Results & Base & \multicolumn{3}{|c|}{ Savings Relative to Base } \\
\hline \multicolumn{2}{|c|}{ Key Characteristics } & Energy Use: & \multirow{7}{*}{$\begin{array}{c}45.7 \\
11.6 \\
\$ 1.00\end{array}$} & \multirow{6}{*}{$\begin{array}{c}1.4 \\
-0.5 \\
\$ 0.03 \\
\$ 0.15\end{array}$} & & \multirow[b]{2}{*}{6.6} \\
\hline Floor space & 10,000 & Electricity (kBtu/sqft/yr) & & & 5.2 & \\
\hline No. of floors & 1 & Nat. Gas (kBtu/sqft/yr) & & & -1.6 & -2.2 \\
\hline Aspect ratio & 2.25 & Energy cost $\quad(\$ / \mathrm{sqft} / \mathrm{yr})$ & & & $\$ 0.10$ & $\$ 0.13$ \\
\hline Core ratio & 0.44 & Life-cycle cost $\quad$ (\$/sqft) & & & $\$ 0.98$ & $\$ 1.12$ \\
\hline \multirow{2}{*}{$\begin{array}{l}\text { Window-wall ratio } \\
\text { Economizer (?) }\end{array}$} & 0.38 & & & & & \multirow[b]{2}{*}{$\begin{array}{c}3.5 \\
10.4 \%\end{array}$} \\
\hline & no & $\begin{array}{r}\text { Savings-to-invest. Ratio } \\
\text { Adjusted IRR }\end{array}$ & & $\begin{array}{c}1.8 \\
8.6 \%\end{array}$ & $\begin{array}{c}4.7 \\
11.2 \%\end{array}$ & \\
\hline \multicolumn{2}{|c|}{ Large Office (WWR=0.18) } & Normalized Results & Base & \multicolumn{3}{|c|}{ Savings Relative to Base } \\
\hline \multicolumn{2}{|c|}{ Key Characteristics } & Energy Use: & \multirow{7}{*}{$\begin{array}{c}42.2 \\
6.2 \\
\$ 0.91\end{array}$} & & & \\
\hline Floor space & 60,000 & Electricity (kBtu/sqft/yr) & & 1.6 & 4.7 & 6.3 \\
\hline No. of floors & 3 & Nat. Gas (kBtu/sqft/yr) & & 1.2 & -1.1 & 0.2 \\
\hline Aspect ratio & 2.25 & Energy cost $\quad(\$ /$ sqft/yr $)$ & & $\$ 0.04$ & $\$ 0.09$ & $\$ 0.13$ \\
\hline Core ratio & 0.59 & Life-cycle cost $\quad$ (\$/sqft) & & $\$ 0.12$ & $\$ 0.88$ & $\$ 1.01$ \\
\hline \multirow{2}{*}{$\begin{array}{l}\text { Window-wall ratio } \\
\text { Economizer (?) }\end{array}$} & 0.18 & & & & & \\
\hline & yes & $\begin{array}{r}\text { Savings-to-invest. Ratio } \\
\text { Adjusted IRR }\end{array}$ & & $\begin{array}{c}1.3 \\
7.8 \%\end{array}$ & $\begin{array}{c}4.3 \\
11.0 \%\end{array}$ & $\begin{array}{c}2.6 \\
9.6 \%\end{array}$ \\
\hline \multicolumn{2}{|c|}{ Large Office (WWR=0.38) } & Normalized Results & Base & Savings & Relative & to Base \\
\hline Key Charac & ristics & Energy Use: & & & & \\
\hline Floor space & 60,000 & Electricity (kBtu/sqft/yr) & 43.5 & 1.0 & 4.7 & 5.7 \\
\hline No. of floors & 3 & Nat. Gas (kBtu/sqft/yr) & 6.6 & -0.3 & -1.1 & -1.5 \\
\hline Aspect ratio & 2.25 & Energy cost $\quad(\$ / \mathrm{sqft} / \mathrm{yr})$ & $\$ 0.94$ & $\$ 0.02$ & $\$ 0.09$ & $\$ 0.11$ \\
\hline Core ratio & 0.59 & Life-cycle cost $\quad$ (\$/sqft) & & $\$ 0.11$ & $\$ 0.88$ & $\$ 0.99$ \\
\hline Window-wall ratio & 0.38 & & & & & \\
\hline Economizer (?) & yes & Savings-to-invest. Ratio & & 1.9 & 4.3 & 3.5 \\
\hline & & Adjusted IRR & & $8.7 \%$ & $11.0 \%$ & $10.4 \%$ \\
\hline
\end{tabular}


Table 9 indicates that the cost effectiveness of the 1999 standard is relatively constant across all the offices considered. The lighting-only SIR and AIRR values are slightly lower for the large office than the small office. This difference is likely due to the presence of an economizer in the large office. In the small office, the cooling equipment must meet all changes in the cooling loads. The envelope-only SIR and AIRR values are slightly higher for the buildings with higher window-to-wall ratios, as differences in first cost requirements between the base case and 90.1-1999 case for these buildings is relatively less than the incremental first costs requirements for buildings with lower window-to-wall ratios.

\subsection{Retail}

Table 10 shows the normalized summary results for the retail, education, and food service buildings analyzed. The detailed engineering and cost tables (similar to Table 7 and Table 8 above) for these buildings are shown in Appendix B.

The top panel of Table 10 shows the summary results for a single-story, 24,000 square foot, retail building. Figure 4 provides an illustration of a retail building with these characteristics. The lighting-only case for retail shows larger absolute reductions in total energy consumption, stemming largely from the relatively large difference in the LPD between the base case and 1999 standard. Even under the assumption that the reduction in LPD between the 1989 level of 2.36 watts $/ \mathrm{ft}^{2}$ and the 1999 level of 1.9 watts $/ \mathrm{ft}^{2}$ is accomplished entirely by changes to more efficient (and more expensive) technologies, the change is still cost effective. The savings-to-investment ratio is 4.7 and the adjusted IRR is over $10 \%$.

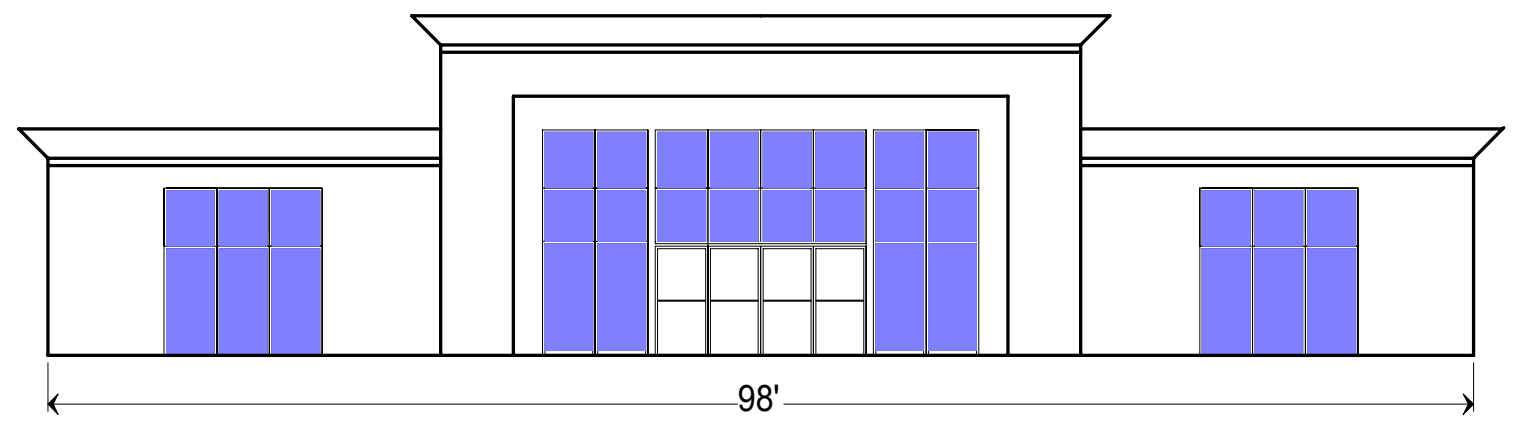

Figure 4. Retail Building - 24,000 s.f. with 7\% window-to-wall ratio

While the base electricity consumption per square foot is higher in the retail building as compared to any of the office buildings (due, in large part, to higher lighting levels), the reduction in electricity intensity $\left(\mathrm{MMBtu} / \mathrm{ft}^{2}\right)$ from the 1999 envelope requirements is only about half that of offices. Although the requirements for the window shading coefficient increases in the 1999 standard, the smaller window area in most retail buildings (simulated here with a window-to-wall ratio of 0.07 ) diminishes the influence of this requirement on total energy use. The building footprint is also similar to the large office analyzed. The smaller ratio of the envelope area to total floor space reduces the energy and cost savings per square foot (as compared to the small office). The net effect 
is an increase in life-cycle cost of $\$ .17$ per square foot. The combined effect of lighting and envelope, however, is a net decrease in life-cycle cost of nearly $\$ 35,000$ relative to the base case.

\subsection{Education}

The two education buildings analyzed are shown in Table 10 and the detailed engineering cost tables are provided in Appendix B. The first is intended to represent a typical elementary school - a single story building with classrooms on either side of a hallway (See Figure 5). The second building is more likely to be found at a secondary school or college campus - two floors with a slightly smaller footprint than the elementary school (See Figure 6). Both buildings were simulated with a window-to-wall ratio of 0.18.

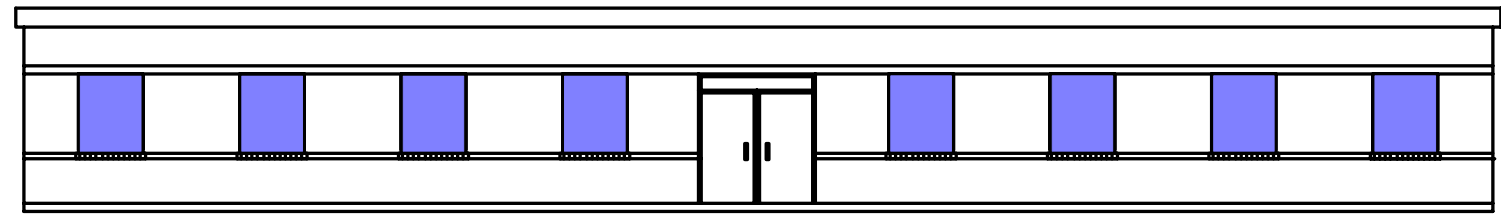

Figure 5. Education Building (Elementary) - 50,000 s.f., $18 \%$ window-to-wall ratio

The lower annual fuel costs lead to life-cycle cost savings for both education buildings. On a per square foot basis, the life-cycle cost savings are slightly higher for the two-story school. The lighting-only case shows that the ASHRAE 90.1-1999 requirements for reduced LPDs in education buildings is cost effective with an SIR that exceeds 3 and the adjusted rate of return is more than $10 \%$. The shorter operating hours for these buildings is reflected in the economic measures. The SIR and AIRR measures for the two education buildings are lower than the corresponding measures for office and retail buildings.

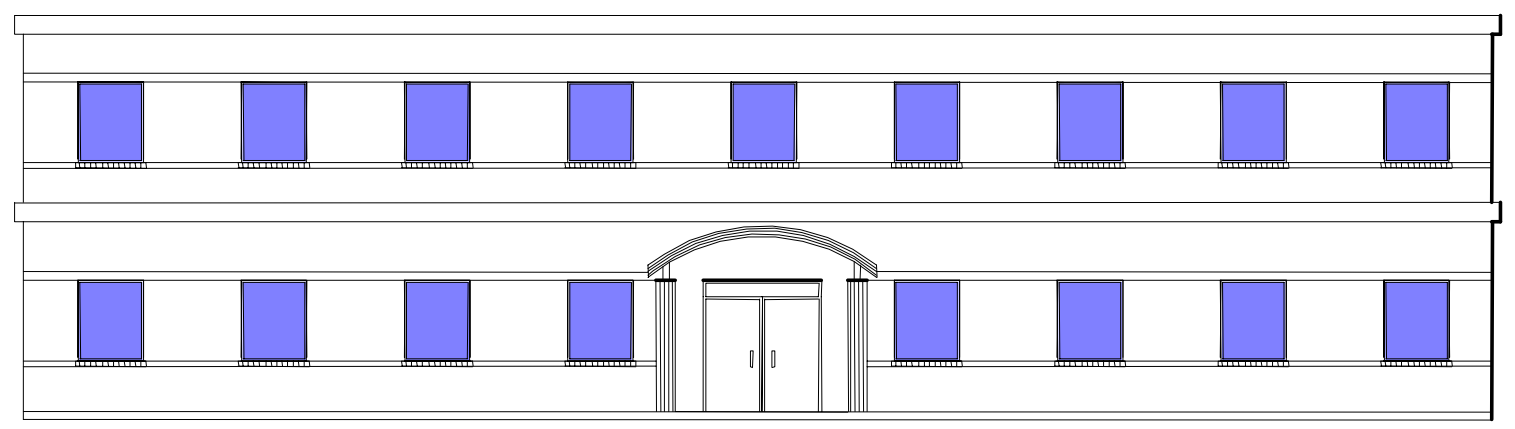

Figure 6. Education Building - 80,000 s.f. with 18\% window-to-wall ratio. 
Table 10. Summary of Results for Retail, Education, and Restaurants

\begin{tabular}{|c|c|c|c|c|c|c|}
\hline \multirow[t]{2}{*}{ Location: } & \multicolumn{2}{|l|}{ Michigan } & \multicolumn{4}{|c|}{ Standard Level } \\
\hline & & & $\begin{array}{l}90.1-1989 \\
\text { Base }\end{array}$ & $\begin{array}{c}90.1-1999 \\
\text { Envelope } \\
\text { Only }\end{array}$ & $\begin{array}{c}\text { 90.1- } \\
1999 \\
\text { Lighting } \\
\text { Only }\end{array}$ & $\begin{array}{l}90.1-1999 \\
\text { Envelope } \\
\text { \& Lighting }\end{array}$ \\
\hline \multicolumn{2}{|c|}{ Retail } & Normalized Results & Base & \multicolumn{3}{|c|}{ Savings Relative to Base } \\
\hline \multicolumn{2}{|c|}{ Key Characteristics } & Energy Use: & \multirow{7}{*}{$\begin{array}{c}49.6 \\
5.1 \\
\$ 1.06\end{array}$} & & & \\
\hline Floor space & 24,000 & Electricity (kBtu/sqft/yr) & & 0.2 & 8.1 & 8.3 \\
\hline No. of floors & 1 & Nat. Gas (kBtu/sqft/yr) & & 2.0 & -1.5 & 1.0 \\
\hline Aspect ratio & 2.50 & Energy cost $\quad(\$ /$ sqft/yr) & & $\$ 0.01$ & $\$ 0.16$ & $\$ 0.18$ \\
\hline Core ratio & 0.61 & Life-cycle cost $\quad$ (\$/sqft) & & $-\$ 0.17$ & $\$ 1.57$ & $\$ 1.44$ \\
\hline Window-wall ratio & 0.07 & & & & & \\
\hline Economizer (?) & no & $\begin{array}{r}\text { Savings-to-invest. Ratio } \\
\text { Adjusted IRR }\end{array}$ & & $\begin{array}{c}0.5 \\
5.2 \%\end{array}$ & $\begin{array}{c}4.7 \\
11.2 \%\end{array}$ & $\begin{array}{c}2.9 \\
9.9 \%\end{array}$ \\
\hline \multicolumn{2}{|c|}{ Education (elementary) } & Normalized Results & Base & \multicolumn{3}{|c|}{ Savings Relative to Base } \\
\hline \multicolumn{2}{|c|}{ Key Characteristics } & Energy Use: & \multirow{7}{*}{$\begin{array}{c}30.0 \\
23.2 \\
\$ 0.73\end{array}$} & & & \\
\hline Floor space & 50,000 & Electricity (kBtu/sqft/yr) & & 1.2 & 3.5 & 4.8 \\
\hline No. of floors & 1 & Nat. Gas (kBtu/sqft/yr) & & 1.6 & -1.6 & 0.0 \\
\hline Aspect ratio & 6.00 & Energy cost $\quad$ (\$/sqft/yr) & & $\$ 0.03$ & $\$ 0.07$ & $\$ 0.10$ \\
\hline Core ratio & 0.63 & Life-cycle cost $\quad(\$ /$ sqft $)$ & & $\$ 0.05$ & $\$ 0.58$ & $\$ 0.63$ \\
\hline Window-wall ratio & 0.18 & & & & & \\
\hline Economizer (?) & no & $\begin{array}{r}\text { Savings-to-invest. Ratio } \\
\text { Adjusted IRR }\end{array}$ & & $\begin{array}{c}1.1 \\
7.3 \%\end{array}$ & $\begin{array}{c}3.4 \\
10.3 \%\end{array}$ & $\begin{array}{c}2.0 \\
8.9 \%\end{array}$ \\
\hline \multicolumn{2}{|c|}{ Education (two-story) } & Normalized Results & Base & \multicolumn{3}{|c|}{ Savings Relative to Base } \\
\hline \multicolumn{2}{|c|}{ Key Characteristics } & Energy Use: & \multirow{7}{*}{$\begin{array}{c}31.7 \\
20.4 \\
\$ 0.76\end{array}$} & & & \\
\hline Floor space & 80,000 & Electricity (kBtu/sqft/yr) & & 1.7 & 3.6 & 5.3 \\
\hline No. of floors & 2 & Nat. Gas (kBtu/sqft/yr) & & 1.4 & -1.5 & -0.1 \\
\hline Aspect ratio & 5.00 & Energy cost $\quad(\$ /$ sqft/yr $)$ & & $\$ 0.04$ & $\$ 0.07$ & $\$ 0.11$ \\
\hline Core ratio & 0.62 & Life-cycle cost $\quad$ (\$/sqft) & & $\$ 0.18$ & $\$ 0.61$ & $\$ 0.78$ \\
\hline Window-wall ratio & 0.18 & & & & & \\
\hline Economizer (?) & no & $\begin{array}{r}\text { Savings-to-invest. Ratio } \\
\text { Adjusted IRR }\end{array}$ & & $\begin{array}{c}1.5 \\
8.1 \%\end{array}$ & $\begin{array}{c}3.5 \\
10.4 \%\end{array}$ & $\begin{array}{c}2.3 \\
9.3 \%\end{array}$ \\
\hline \multicolumn{2}{|c|}{ Family Restaurant } & Normalized Results & Base & \multicolumn{3}{|c|}{ Savings Relative to Base } \\
\hline \multicolumn{2}{|c|}{$\begin{array}{l}\text { Key Characteristics } \\
\end{array}$} & Energy Use: & \multirow{7}{*}{$\begin{array}{c}94.3 \\
40.8 \\
\$ 2.15\end{array}$} & \multirow{6}{*}{$\begin{array}{c}3.0 \\
1.6 \\
\$ 0.07 \\
\$ 0.21\end{array}$} & \multirow[b]{2}{*}{9.0} & \multirow[b]{2}{*}{12.0} \\
\hline Floor space & 5,000 & Electricity (kBtu/sqft/yr) & & & & \\
\hline No. of floors & 1 & Nat. Gas (kBtu/sqft/yr) & & & -2.9 & -1.9 \\
\hline Aspect ratio & 2.00 & Energy cost $\quad$ (\$/sqft/yr) & & & $\$ 0.17$ & $\$ 0.24$ \\
\hline Core ratio & 0.28 & Life-cycle cost $\quad$ (\$/sqft) & & & $\$ 1.87$ & $\$ 2.04$ \\
\hline \multirow{2}{*}{$\begin{array}{l}\text { Window-wall ratio } \\
\text { Economizer (?) }\end{array}$} & 0.18 & & & & & \\
\hline & yes & $\begin{array}{r}\text { Savings-to-invest. Ratio } \\
\text { Adjusted IRR }\end{array}$ & & $\begin{array}{c}1.3 \\
7.7 \%\end{array}$ & $\begin{array}{c}7.8 \\
12.6 \%\end{array}$ & $\begin{array}{c}3.1 \\
10.1 \%\end{array}$ \\
\hline
\end{tabular}




\subsection{Restaurants}

The results of the restaurant (food service) building analyzed are shown in Table 10 and the detailed engineering cost tables are provided in Appendix B. The bottom panel of Table 10 shows the summary results for a single-story, 5,000 square foot, family restaurant building, with $18 \%$ of the exterior walls made up of windows.

The base electricity consumption per square foot is higher for the food service building as compared to any of the other buildings modeled, and the reduction in electricity intensity $\left(\mathrm{MMBtu} / \mathrm{ft}^{2}\right)$ from the 1999 envelope requirements is greater than the other buildings modeled. With the exception of the slab insulation requirement, all envelope requirements become more stringent under the ASHRAE 90.1-1999, leading to electric and gas savings and positive net life cycle savings.

On a per square foot basis, the life-cycle cost savings results are similar to the results for the retail buildings. The lighting-only case shows that the ASHRAE 90.1-1999 requirements for reduced LPDs in family restaurants would be highly cost effective. The SIR exceeds 7 and the adjusted rate of return is more than $12 \%$.

\subsection{Other Factors Impacting Benefits and Costs}

There are numerous areas of the ASHRAE 90.1-1999 standard that are not easily valued and modeled with the quantitative approach taken in this study. Many of these other elements of the standard, however, do have quantitative economic and energy impacts. The following section briefly describes some probable energy benefits and costs of selected components of the ASHRAE 90.1-1999 standards that are not captured in the previous analysis.

\subsubsection{Building Envelope}

ASHRAE 90.1-1999 requires that insulation be installed in substantial contact with the inside surface of cavities. It also requires that lighting fixtures, heating, ventilating, and air-conditioning, and other equipment not be recessed in such a manner as to affect the insulation performance. Finally, the 1999 edition bans installation of insulation on suspended ceilings with removable ceiling panels. The 1980 edition does not address this subject. The ASHRAE 90.1-1999 insulation installation requirements are expected to save energy in commercial buildings relative to the ASHRAE 90A-1980 baseline.

For cooler climates, ASHRAE 90A-1980 requires between R-7 to R-8 slab-on-grade insulation, while ASHRAE 90.1-1999 has no such requirement. This is expected to result in higher heating loads in cold climates with ASHRAE 90.1-1999 and thus result in a net reduction in energy savings relative to the 1980 edition. 


\subsubsection{Lighting}

One of the more significant lighting requirement elements of ASHRAE 90.1-1999 that was not included in the quantitative results is the lighting control requirement. Lighting controls, such as occupancy sensors, have the potential to significantly reduce energy use by switching off electrical lighting loads when a normally occupied area is vacated.

Manufacturers claim savings of $15 \%$ to $85 \%$, although there is little published research to support the magnitude or timing of reductions. Energy savings and performance are directly related to the total wattage of the load being controlled, effectiveness of the previous control method, occupancy patterns within the space and proper sensor commissioning. Case studies of energy savings have had varied results due largely to differences in human factors, previous control strategies, and proper sensor commissioning (Floyd 1997).

In the area of lighting controls, ASHRAE 90.1-1999 specifies that a building utilize a "whole-building controller," at a minimum. Although a whole building controller is a relatively low-cost lighting control solution, it is not very practical for many applications and therefore it is unlikely that this would be the alternative choice for most building designs. More likely, a building design would incorporate something like occupancy sensors; however, this is above and beyond the minimal ASHRAE requirement, which makes the evaluation of the code impacts with regard to lighting controls difficult to assess. It is expected, however, that including a lighting control requirement should save energy.

There are a number of lighting exemptions in ASHRAE 90A-1980 that are not included in the 1999 edition, such as commercial greenhouses and process facilities. These changes would be expected to result in some reduction in lighting power use with the adoption of ASHRAE 90.1-1999. On the other hand, there are also a number of narrowly-targeted exemptions in the 1999 edition that are not in the ASHRAE 90A-1980. The net effect of these differences, however, is expected to be a small increase in lighting efficiency with ASHRAE 90.1-1999 relative to the 1989 edition.

\subsubsection{Mechanical and SWH}

There are significant changes to HVAC and SWH equipment efficiencies between 90A-1980 and 90.1-1999; however, most of this equipment is covered by federal manufacturing standards whose adoption by federal statute will set their efficiencies at least as high as those in the latest version of ASHRAE 90.1 within a relatively short time frame. Chillers, however, which are not covered under manufacturing standards have significantly higher efficiencies under ASHRAE 90.1-1999. In addition, 90.1-1999 sets requirements for heat rejection equipment (fluid coolers and cooling towers) as well as for absorption chillers that were not addressed in 90A-1980. Two other significant additions to 90.1-1999 include more stringent performance requirements for variable speed fan systems as well as the addition of requirements for heat recovery. The 90.11999 standard has dropped much of the non-enforceable language as well as difficult to enforce requirements that were in the 90A-1980 standard. There are other differences between the mechanical systems, the bulk of which can be reviewed online at http://www.energycodes.gov/implement/determinations_com.stm. 


\subsubsection{Scope of Standard}

One dominating factor influencing potential impacts of costs and benefits of adopting ASHRAE 90.1-1999 is the inclusion of alterations and renovations to the scope of the standard. This greatly expands the scope of the standard beyond ASHRAE 90A-1980, which only applied to new buildings or new portions of existing buildings (additions). While it is difficult to quantify the energy efficiency impact of alterations and renovations, the U.S. Census Bureau 1997 Construction Geographic Area Series reports that the dollar value of commercial construction devoted to additional, alterations, or reconstruction in Michigan was $\$ 3$ billion in 1997, as compared to new building construction valued at $\$ 6$ billion (2000c). If the value of annual investment in building alterations and renovations is a good indicator of its impact on energy use, then the expansion of this code to existing buildings could produce approximately $50 \%$ more savings than if it were applied exclusively to new buildings. 


\subsection{Qualitative Considerations}

In comparing ASHRAE 90.1-1999 to ASHRAE 90A-1980, various revisions have been made in an effort to make the standard clearer and easier to enforce. For example, the inclusion of specific direction on how to calculate luminaire power in ASHRAE Standard 90.1-1999 is expected to eliminate some under-calculation of lighting power, which may lead to lower energy usage for lighting. In addition, various language and formatting changes have been made to make the standard easier to apply.

While the ASHRAE Standard 90A-1980 provided climate-specific guidance by using example cities, the ASHRAE Standard 90.1-1999 provides requirements in terms of "climate bins" that cover a larger area. This allows builders to more easily find an appropriate climate for the area in which they are building. The ASHRAE Standard 90.11999 also simplifies the code compliance for smaller-scale construction by providing a "Simplified Approach Option for HVAC Systems." This section condenses the mechanical system requirements for a large class of simple systems.

ASHRAE Standard 90.1-1999 is written in mandatory, enforceable language. ASHRAE Standard 90A-1980 contains guidance written as suggestive statements, which may complicate enforcement and compliance if not properly defined and revised. ASHRAE 90.1-1999 also provides specific guidance for applying the code to existing building alternations and additions. From an energy savings standpoint, any changes that make ASHRAE Standard 90.1-1999 easier to understand and enforce may have a small positive impact on energy savings. 


\subsection{Conclusions}

One of the primary differences between the development of the ASHRAE 90A-1980 and 1989 is that ASHRAE 90.1-1999 is based more heavily on economic justification for envelope requirements. The ASHRAE 90.1-1999 envelope requirements were developed under a minimum life-cycle cost process that balances the energy savings achieved by setting the requirement at a particular level against the cost of equipment associated with that level of efficiency. The results of this limited study appear to confirm that the ASHRAE 90.11999 standard has succeeded, for the most part, in developing cost-justified energy savings for these building types. Figure 7 provides a comparison of the LCC savings per square foot by building type for envelope and lighting requirements, individually and together.

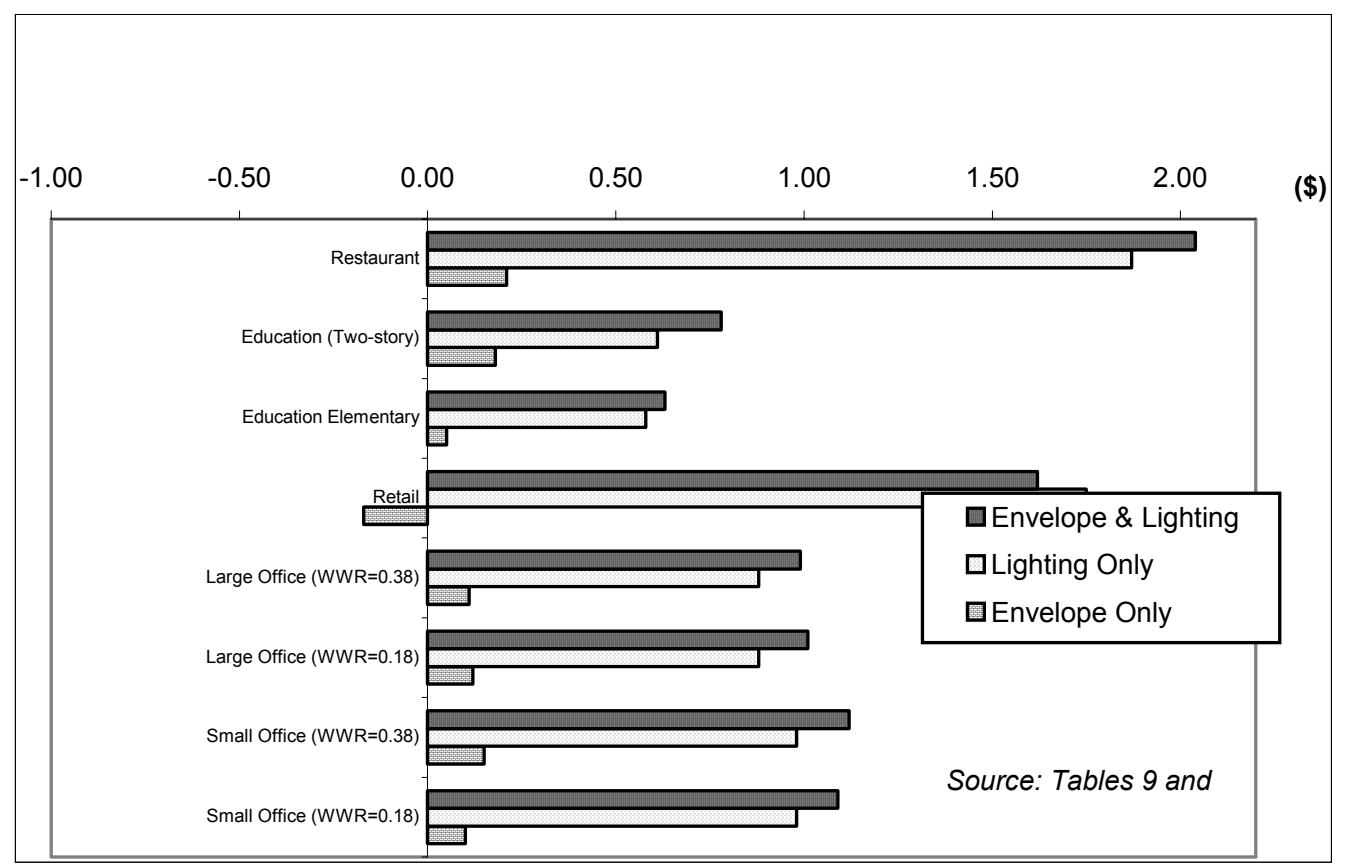

Figure 7. A Comparison of Life Cycle Cost Saving Per Square Foot Between Different Types of Buildings

The ASHRAE 90.1-1999 lighting requirements appear to be highly cost-effective for these building types in terms of LCC savings relative to the 90A-1980 (modeled as 90.1-1989) baseline. These results are obtained assuming the light levels in the space are maintained at the IES recommended light levels used in development of the 90.1-1999 lighting power densities, but that the 90.1-1999 levels require the use of more efficient lamp and ballast technologies. When lighting and envelope requirements are combined, all of the buildings simulated display savings in energy use, annual fuel cost, and life-cycle costs. Based on these limited quantitative results, it appears that adopting the ASHRAE 90.1-1999 standard in Michigan would provide positive net economic benefits to the state relative to the building and design requirements prescribed in ASHRAE 90A-1980.

In addition to quantitative benefits, it appears that ASHRAE 90.1-1999 may also provide other advantages over ASHRAE 90A-1980 in achieving compliance. ASHRAE 90.1-1999 has significantly modified the structure and language of the standard in effort to make it easier to understand, use, and enforce. 


\subsection{References}

American Society of Heating, Refrigerating and Air-Conditioning Engineers (ASHRAE) and Illuminating Engineering Society of North America (IESNA). 1999. ASHRAE Standard Energy Standard for Buildings Except Low-Rise Residential Buildings.

Energy Information Administration (EIA). 2001a. "Annual Electric Utility Report," and EIA-826, "Monthly Electric Utility Sales and Revenue Report with State Distributions." EIA-861, U.S. Department of Energy. Summer, 2001. Washington D.C.

Energy Information Administration (EIA). 2001b. Annual Energy Outlook 2002 with Projections to 2020. U.S. Department of Energy. December 2001. Washington D.C.

Energy Information Administration (EIA). 1992. Commercial Building Energy Consumption and Expenditures Survey 1992 (CBECS 92), Public Use Data, Micro-data files on EIA website. [Online].

Available: ftp://ftp.eia.doe.gov/pub/consumption/commercial/micro.data/

U.S. Department of Energy. Washington D.C.

Energy Information Administration (EIA). 1995. Commercial Building Energy Consumption and Expenditures Survey 1995 (CBECS 95), Public Use Data, Micro-data files on EIA website. [Online].

Available: ftp://ftp.eia.doe.gov/pub/consumption/commercial/micro.data/ U.S. Department of Energy. Washington D.C.

Energy Information Administration (EIA). 2000. National Energy Modeling System (NEMS) U.S. Department of Energy. 2000. Washington D.C.

Energy Information Administration (EIA). 2001c. "State Energy Profiles," U.S. Department of Energy. August 2001. Washington D.C.

Floyd, D. et. al. "Measured Field Performance and Energy Savings of Occupancy Sensors: Three Case Studies.” FSEC-PF309, 1997. [Online]. Available: http://www.fsec.ucf.edu/ bdac/pubs/PF309/PF309.htm, accessed 02/01.

National Institute of Standards and Technology (NIST). "Energy Price Indices and Discount Factors for Life-Cycle Cost Analysis." NISTIR 85-3273-16, U.S. Department of Commerce, April 2001. Washington D.C.

Office of Management and Budget (OMB). 1992. Guidelines and Discount Rates for Benefit-Cost Analyses of Federal Programs. OMB Circular A-94. [Online].

Available: http://www.whitehouse.gov/OMB/circulars/a094/a094.html

Somasundaram, S. et. al. 2000. Screening Analysis for EPACT-Covered Commercial HVAC and Water-Heating Equipment. Pacific Northwest National Laboratory, PNNL-13232. April 2000. 
Smith, LA and Nadel. S (1994). Energy Efficiency Codes and Standards for Michigan. American Council for an Energy-Efficiency Economy (ACEEE), May, 1994.

Washington D.C.

U.S. Bureau of Labor Statistics (BLS). 2002. Producer Price Index Industry Series. Public Use Data on BLS website. [Online].

Available: http://data.bls.gov/labjava/outside/jsp?survey $=p c$.

U.S. Census Bureau (Census). 2000a. Construction Reports, Series C-40, "Housing Units Authorized by Building Permits." U.S. Department of Commerce, Spring, 2000. Washington D.C.

U.S. Census Bureau (Census). 2000b. United States Census 2000. U.S. Department of Commerce, April 2000, Washington D.C.

U.S. Census Bureau (Census). 2000c. "1997 Economic Census Construction

Geographic Area Series." U.S. Department of Commerce, March 2000. Washington

D.C.Energy

U.S. Department of Energy (DOE) 2000. January 2000. "Fluorescent Lamp Ballast Technical Support Document." Available online DOE website: [Online].

Available: http://www.eren.doe.gov/buildings/codes_standards/reports/ballasts/index.htm

W. W. Grainger Industrial Supply - Lighting Catalog 2000-01. 2000. W. W. Grainger, Incorporated. Lake Forest, IL. 


\section{APPENDIX A \\ Glossary of Selected Terms}




\section{Glossary}

Ballast: a device used in conjunction with an electric-discharge lamp to cause the lamp to start and operate under the proper circuit conditions of voltage, current, wave form, electrode heat, etc.

Building Envelope: the exterior plus the semi-exterior portions of a building. For the purposes of determining building envelope requirements, the classifications are defined as follows:

(a) building envelope, exterior: the elements of a building that separate conditioned space from the exterior.

(b) building envelope, semi-exterior: the elements of a building that separate conditioned space from unconditioned space or that enclose semi-heated spaces through which thermal energy may be transferred to or from the exterior, or to or from unconditioned spaces, or to or from conditioned spaces.

CDD50 Cooling Degree-Day base $50^{\circ} \mathrm{F}$ : for any one day, when the mean temperature is more than $50^{\circ} \mathrm{F}$, there are as many degree-days as degree Fahrenheit temperature difference between the mean temperature for the day and $50^{\circ} \mathrm{F}$. Annual cooling degreedays (CDDs) are the sum of the degree-days over a calendar year.

C-factor (thermal conductance): time rate of steady state heat flow through unit area of a material or construction, induced by a unit temperature difference between the body surfaces. Units of $\mathrm{C}$ are $\mathrm{Btu} / \mathrm{h} \cdot \mathrm{ft}^{2}{ }^{\circ} \mathrm{F}$. Note that the $\mathrm{C}$-factor does not include soil or air films.

Envelope performance factor: the trade-off value for the building envelope performance compliance option calculated using the procedure in Section 5 of the ASHRAE/IESNA Standards 90.1-1999.

F-factor: the perimeter heat loss factor for slab-on-grade floors, expressed in $\mathrm{Btu} / \mathrm{h} \cdot \mathrm{ft}^{2}{ }^{\circ} \mathrm{F}$

HDD65 Heating Degree-Day base $65^{\circ} \mathrm{F}$ : for any one day, when the mean temperature is less than $65^{\circ} \mathrm{F}$, there are as many degree-days as degree Fahrenheit temperature difference between the mean temperature for the day and $65^{\circ} \mathrm{F}$. Annual heating degreedays (HDDs) are the sum of the degree-days over a calendar year.

HVAC system: the equipment, distribution systems, and terminals that provide, either collectively or individually, the processes of heating, ventilating, or air conditioning to a building or portion of a building.

Life Cycle Cost (LCC) analysis: is a method of analyzing the cost of a system or a product over its entire lifespan. LCC enables you to define the elements included in the lifespan of a system or product, and assign equations to each element. These equations represent the calculation of the cost of that particular element. 
Shading Coefficient (SC): the ratio of solar heat gain at normal incidence through glazing to that occurring through $1 / 8$ inch thick clear, double-strength glass. Shading coefficient, as used herein, does not include interior, exterior, or integral shading devices.

U-factor (thermal transmittance): heat transmission in unit time through unit area of material or construction and boundary air films, induced by unit temperature difference between the environment and each side. Units of $\mathrm{U}$ are $\mathrm{Btu} / \mathrm{h}{ }^{\circ} \mathrm{F}$.

Source: For details refer to ASHRAE STANDARD, Energy Standard for Buildings Except Low-Rise Residential Buildings. I-P edition. American Society of Heating, Refrigerating and Air-Conditioning Engineers, Inc. 1999. 
APPENDIX B

Results by Building Type 
